\title{
Diffusion-controlled and replacement microtextures in alkali feldspars from two pegmatites: Perth, Ontario and Keystone, South Dakota
}

\author{
Martin R. LeE ${ }^{1, *}$ And IAN PARSONS ${ }^{2}$ \\ 1 School of Geographical and Earth Sciences, University of Glasgow, Lilybank Gardens, Glasgow G12 8QQ, UK \\ 2 Grant Institute of Earth Science, University of Edinburgh, James Hutton Road, Edinburgh EH9 3FE, UK
}

[Received 3 March 2013; Accepted 23 February 2015; Associate Editor: Ray Macdonald]

\section{ABSTRACT}

Macro- and micro-perthitic microclines from pegmatites from Perth, Ontario (Wards catalogue 46 E 0510 ) and Keystone, South Dakota (Wards 46 E 5125) have been studied using light and electron microscopy. A sample of the type perthite from Perth, Ontario (Hunterian Museum, Glasgow, M2361) was compared using light microscopy. It differs in bulk composition and microtexture from the Wards sample. The Perth sample from Wards is a mesoperthite, with sub-periodic $\sim$ mm-thick albite veins near (100), with irregular surfaces. The microcline has regular tartan twins and formed from orthoclase by a continuous process. The Keystone sample is a microperthite, with non-periodic albite veins mainly in $\{110\}$. Irregular tartan twins, volumes of irregular microcline and subgrains suggest that the microcline formed by dissolutionreprecipitation. Microcline in both samples contains semicoherent cryptoperthitic albite films that formed after the development of tartan twins. The bulk compositions of these intergrowths imply exsolution below $\sim 400^{\circ} \mathrm{C}$. Diffusion parameters imply sustained heating for between $0.11 \mathrm{My}$ at $400^{\circ} \mathrm{C}, 1.5 \mathrm{GPa}$ and $8.4 \mathrm{My}$ at $300^{\circ} \mathrm{C}, 1 \mathrm{GPa}$. Unrealistic times are required at $200^{\circ} \mathrm{C}$. Subsequently, the crystals reacted with a fluid leading to replacive growth of the vein perthites. Unusually, Albite twin composition planes in replacive subgrains have sub-periodic dislocations, formed by coalescence of advancing growth twins. Processes that might lead to periodic, replacive intergrowths are discussed. The Perth and Keystone feldspars have been used for experimental work on dissolution during weathering and on anomalous thermoluminescence fading. Their microtextures make them unsuitable for obtaining properties that can be extrapolated to feldspars in general.

Keywords: alkali feldspar, perthite, exsolution, diffusion, replacement, microcline, twinning, dislocations, pegmatite, silicate dissolution, anomalous fading.

\section{Introduction}

ALKALI feldspars are a common and striking constituent of granitic pegmatites. Perhaps because they often form crystals 100 s of mm across they have been little studied at the sub- $\mu \mathrm{m}$ scales accessible by Scanning (SEM) and Transmission Electron Microscopy (TEM). In this paper we present a study of microtextures in three pegmatitic

* E-mail: Martin.Lee@glasgow.ac.uk DOI: 10.1180/minmag.2015.079.7.01 alkali feldspars (microcline), two from near Perth, Ontario and one from Keystone, South Dakota, at $\mathrm{mm}$ to sub- $\mu \mathrm{m}$ scales. One sample, (M2361), was kindly supplied by the Hunterian museum, Glasgow, and is believed to be part of the type specimen of perthite (named by Thomson, 1843) from Otty Lake near Perth. It can be seen by the unaided eye to be a mm-scale intergrowth of sinuous lamellae of two feldspars, one a deep reddish brown, the other a lighter shade of pink. It was only investigated using light microscopy in this work. The second Perth sample, which is a stronger pink colour in hand specimen, and less 
obviously perthitic, was sold by Wards (catalogue 46 E 0510) as perthite from Perth. The Keystone sample was also supplied by Wards (catalogue $46 \mathrm{E}$ 5125).

One or both of the Wards samples have been used in experimental studies related to mineral weathering, by Holdren and Speyer (1985, 1987), Stoessell and Pittman (1990), Anbeek (1992), Hodson et al. (1997), Hodson (1998) and Brantley and Mellott (2000). Rogers and Bennett (2004) used Keystone microcline to study the role of micro-organisms in the release of nutrients from silicates. The feldspars have also been used in work on anomalous thermoluminescence (TL) fading by Baril and Huntley (2003), Meisl and Huntley (2005) and Godfrey-Smith et al. (2005).

Electron Microscopy (EM) methods were used to study these samples because both dissolution and TL fading are fields in which defect microstructure has an important role, although defect microtextures at the scale reported here have not been investigated previously. It was the intention of the workers in both fields that the properties established could be applied to alkali feldspars in general. We know from our own studies (Lee and Parsons, 1995; Lee et al., 1998, Hodson et al., 1997), based on feldspars of normal crystal size from granites, that crystal defects of various types are important factors in the rates and mechanisms of feldspar dissolution and mechanical degradation. As we show below, the microtextures of these pegmatitic feldspars are extremely complex, vary from point-to-point in the samples, and are different in several ways to the types of alkali feldspar common in normal igneous rocks.

A second aim was to investigate the processes producing the perthitic intergrowths and to explore the potential of using feldspar microtextures at the EM scale to understand the geological history of pegmatites. Coherent cryptoperthitic albite lamellae occur in both microclines and we show that their character and periodicity are consistent with existing experimental work on perthite exsolution kinetics by volume diffusion (Yund, 1974; Yund and Davidson, 1978), extrapolated to the range $400-300^{\circ} \mathrm{C}$. The cryptoperthitic microcline is cut by periodic lamellar micro- and macro-perthitic intergrowths at up to $\mathrm{mm}$-scale that could not have developed, on realistic geological timescales, by a continuous diffusional process. Microtextures at the EM scale clearly show that the coarse perthites are formed by replacement. We discuss possible explanations for their periodic character.

\section{Previous work on alkali feldspars from pegmatites}

Smith (1974, Chapter 19) and Smith and Brown (1988, Chapter 19) provide a summary of early work on coarse perthites, many from pegmatites, with numerous light micrographs. Cerný (1994) provides a comprehensive review of the chemical and textural properties and geological relationships of alkali feldspars from pegmatites. These sources illustrate the daunting variety of microtextures visible using light microscopy (LM). Cerný (1994) shows examples of feldspar with coexisting film and vein microperthites, including a sample from near Otty Lake near Perth, Ontario (his fig. 14D) which is probably the same as the Wards sample described here. Laves and Soldatos (1963) include a micrograph of a (010) section of a perthite from Perth, (reproduced by Smith, 1974, fig 19-4) which shows both microperthitic $\mu \mathrm{m}$-scale film lamellae and mm-scale macroperthitic lamellae and lenses in the microcline matrix, with a small angular difference between them. This too is similar to the Wards specimen. The microperthitic lamellae are in the 'Murchison plane', a non-integral plane between $(\overline{6} 01)$ and $(\overline{8} 01)$, the macroperthitic lamellae are in (100).

The first thorough systematic studies of perthites from pegmatites, using light microscopy, were by Andersen (1928), who studied alkali feldspars from 300 Norwegian pegmatites, noting that many contained microperthitic lamellae lying in the 'Murchison plane'. Modern work has shown that such lamellae, with thicknesses typically of $\sim 1 \mu \mathrm{m}$, are fully- or semi-coherent. Willaime and Brown (1974) showed that they lie in the plane of minimum coherency strain energy. Andersen (1928) called microperthites with this orientation 'film perthite', the terminology we use here. Film lamellae of these dimensions form by volume diffusion. The coarsest coherent film lamellae reach $\sim 10 \mu \mathrm{m}$ in thickness, in granulite-facies rocks. See Parsons and Brown (1991) and Brown and Parsons (1993) for reviews.

Alling $(1921,1932,1938)$ stressed the textural differences between feldspars from pegmatites and those in common plutonic rocks. He recognized that many perthites form by replacement, and distinguished 'deuteric' (involving late fluids in a closed magmatic system) and 'hydrothermal' types (fluid introduced from an external source). $\mathrm{He}$ attempted to classify the different morphological types but did not give information on their crystallographic orientation, a vital aspect of any description of an intergrowth. A guide to 

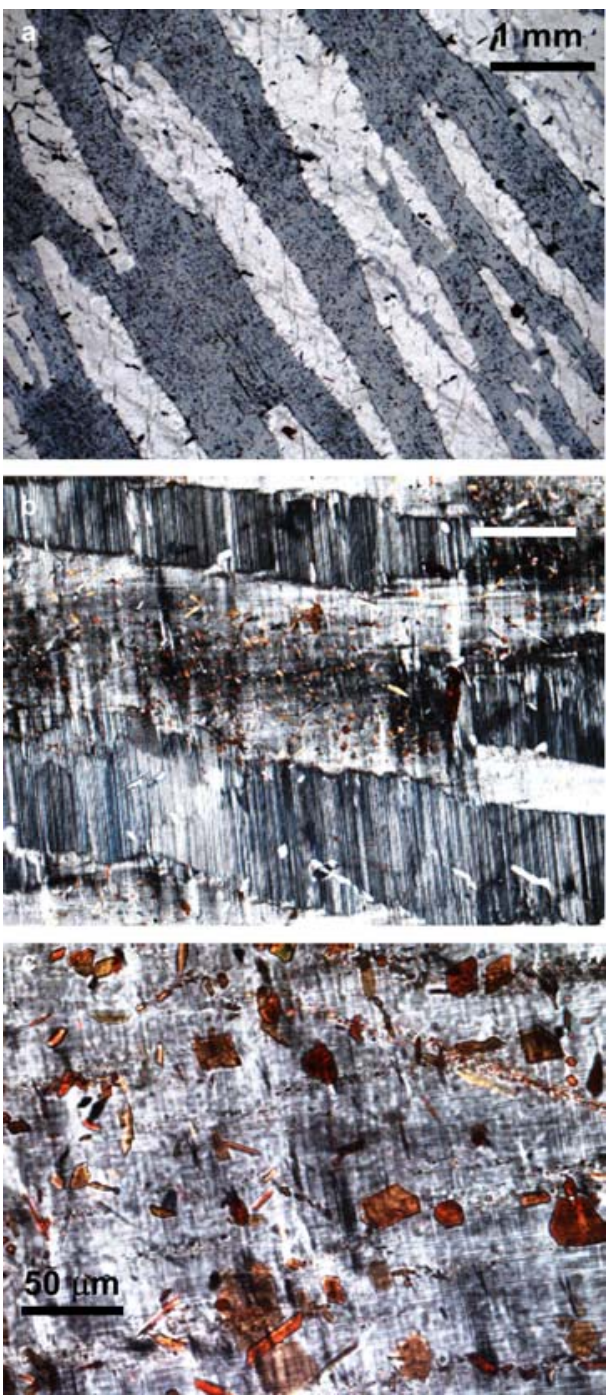

FIG. 1. Light micrographs of Hunterian M2361, probably the type perthite from Perth, Ontario. Crossed polarizers, section parallel to (001). (a) Low magnification image showing lenses of albite (white), with a conspicuous $\{110\}$ cleavage, in microcline (grey). The microcline is crowded with black dots, which are biotite crystals. $(b)$ Albite twinned albite lamellae slightly oblique to $\mathbf{b}$ and fine-scale 'tartan', combined Albite and Pericline twinning, in microcline. In places there is a clear interaction between Albite twins in both phases at the margins of the lamellae. Biotite flakes tend to be concentrated around the centre of the microcline lamellae, although they sometimes occur near margins and rarely in the albite. (c) Thin euhedral flakes of biotite in microcline with very finescale, regular tartan twins. The biotite does not influence the twinning in any way. characterizing intergrowths is provided by Parsons et al. (2015). Soldatos (1962) and Laves and Soldatos (1962, 1963), studied feldspars from pegmatites using single-crystal X-ray diffraction (SXRD). MacKenzie and Smith (1962) included a number of samples from pegmatites in an extensive SXRD study of perthites.

Although the majority of alkali feldspars from pegmatites are turbid and have coarse exsolution microtextures, some have yielded 'gem quality' crystals that have been used for experimental determination of diffusion coefficients. Orthoclase from a pegmatite at Benson Mines in the Adirondacks was used by Foland (1974) to obtain the activation energy and diffusion coefficients for Ar diffusion in K-feldspars. Microtextural information about 'Benson orthoclase' is provided by Parsons and Lee (2005). Another important gem quality pegmatitic alkali feldspar is the yellow ferriferous orthoclase from Itrongay, Madagascar. Unfortunately there are many varieties of 'Madagascar orthoclase' in collections. A set of 20 samples were properly characterized by Coombs (1954), who discovered a considerable range in composition and structural state. Parsons and Lee (2005) summarize the variation in this material, and provide TEM images of very fine-scale exsolution and tweed microtextures in one example, used by Arnaud and Kelly (1997) and Wartho et al. (1999) for work on Ar diffusion. Keefer and Brown (1978) used TEM in a crystal-structural study of a cryptoperthite from a pegmatite from Rabb Canyon, New Mexico. These crystals were cooled rapidly from elevated $T$ and have not experienced the relatively extended cooling and fluid-feldspar reactions usual in granitic pegmatites. White and Barnett (1990) used TEM to study twinning in extremely pure microcline in the Hemlo, Ontario gold ore body but the original grain size is sub-mm.

Very few studies of ordinary 'garden quality' pegmatitic feldspars have been undertaken using SEM and TEM methods and all have concentrated on specific aspects of the feldspar microtextures. Aberdam (1965) carried out pioneering work on the relationship between dislocations and exsolution lamellae. Fitz Gerald and McLaren (1982) investigated Albite and Pericline twinning in microcline from several pegmatites and Sheets and Tettenhorst (1997) studied replacement of pegmatitic feldspar by clay minerals. Sánchez-Muñoz et al. (1998) studied six adularia crystals from Alpine veins using high-resolution TEM (HRTEM) and nuclear magnetic resonance spectroscopy, confirming that they have the coherent tweed domain microtexture 

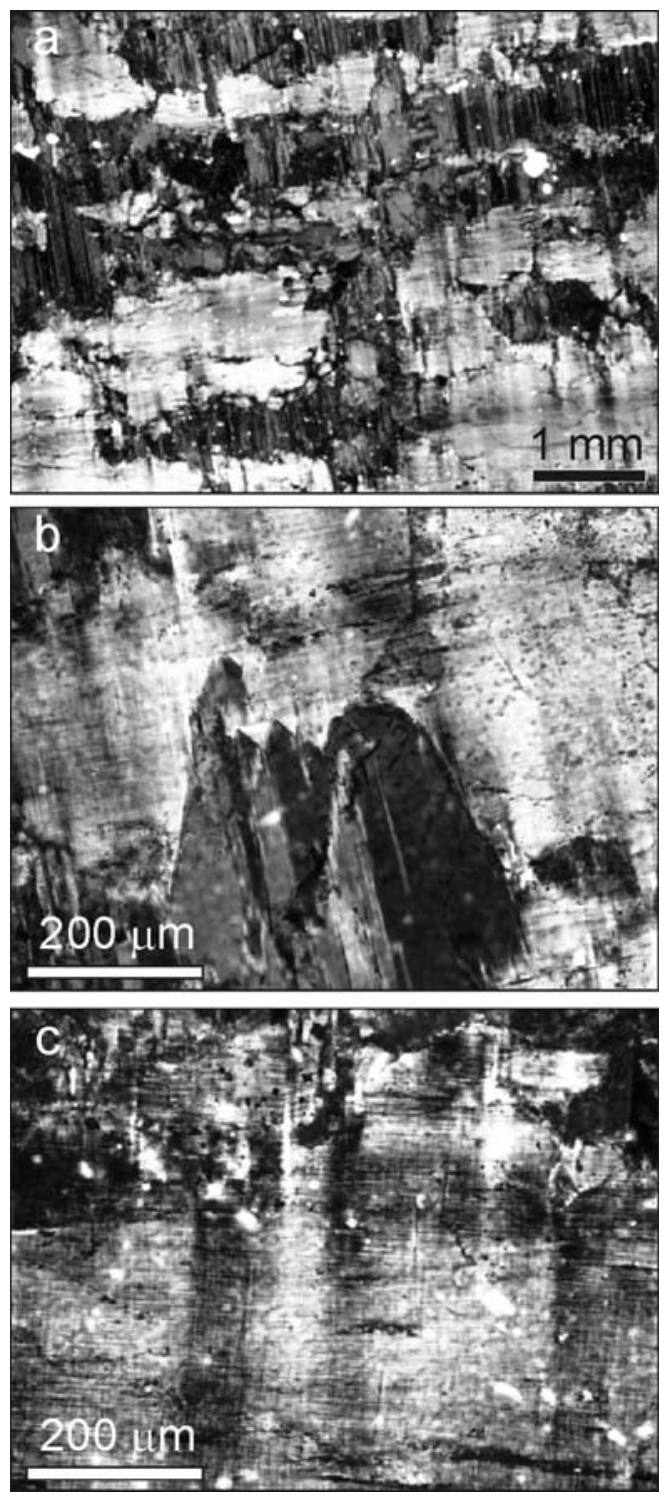

FIG. 2. Light micrographs of Wards sample 46 E 0510 of perthite from Perth, Ontario. Crossed polarizers, section parallel to (001). (a) Low magnification image showing irregular films of Albite-twinned albite (dark grey), predominantly parallel to $\mathbf{b}$, in tartan microcline (lighter grey). In the centre of the micrograph the films can be seen to be composed of discrete, slightly mis-aligned subgrains. (b) Detail of serrated edge of Albite twinned albite lamella and fine-scale tartan twinning in microcline. At this scale there is no obvious coupling between Albite twins in the two phases. (c) Microcline with very finescale, regular tartan twins with superimposed broad fluctuations in the Albite twin orientation.
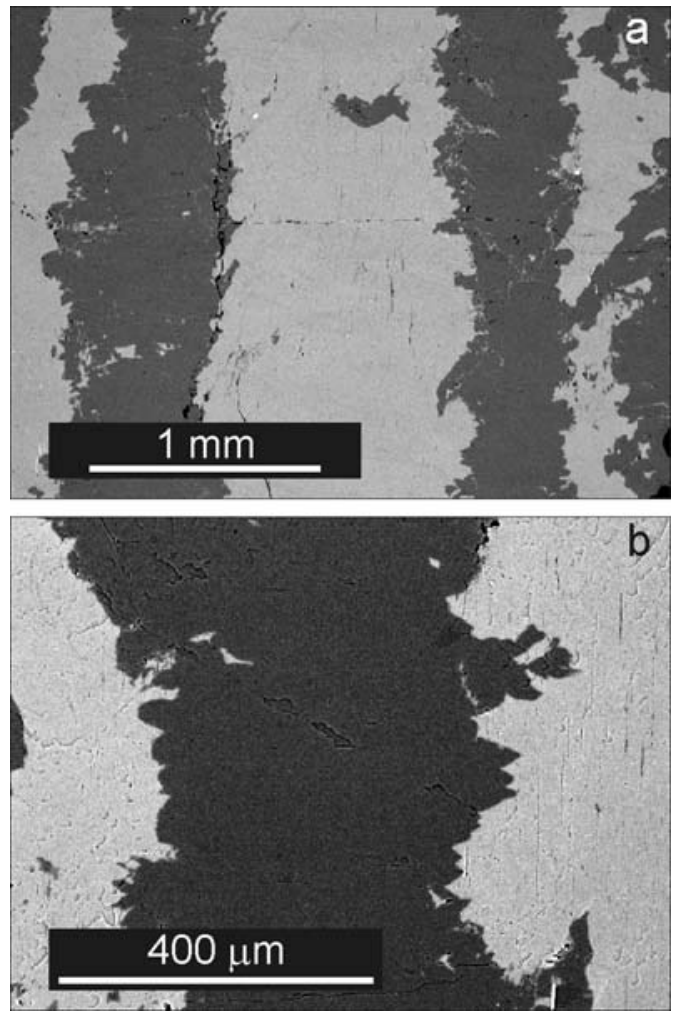

FIG. 3. Perth. BSE images in the SEM of a polished (001) section. All subsequent SEM images are similarly orientated. (a) Complex, macroperthitic albite lamellae (dark grey) in a micro- and crypto-perthitic microcline matrix (light grey). Thin vertical lenses in the microcline in the centre are microperthitic albite lamellae, parallel to $\mathbf{b}$. (b) Detail of a single macroperthitic albite lamella. Note the complex surfaces strongly reminiscent of the fractal Mandelbrot set. Microperthitic lamellae, parallel to $\mathbf{b}$, are just visible in the matrix microcline, particularly at the right.

characteristic of orthoclase (Eggleton and Buseck, 1980). Sánchez-Muñoz et al. (2006) used cathodoluminescence $(\mathrm{CL})$ and SEM imaging to characterize twinning and exsolution features in a 'giant' microcline from the Golconda pegmatite, Minas Gerais, which has both macroperthitic veins and microperthitic film lamellae. Sánchez-Muñoz et al. (2008) studied the orthoclase-microcline transformation in a K-feldspar from a granite pegmatite from Lavra do Fermín, Minas Gerais, using LM. The crystal has very coarse lenticular albite lamellae on scales of $100 \mathrm{~s}$ of $\mu \mathrm{m}$ set in a predominantly orthoclase matrix, and long-range 

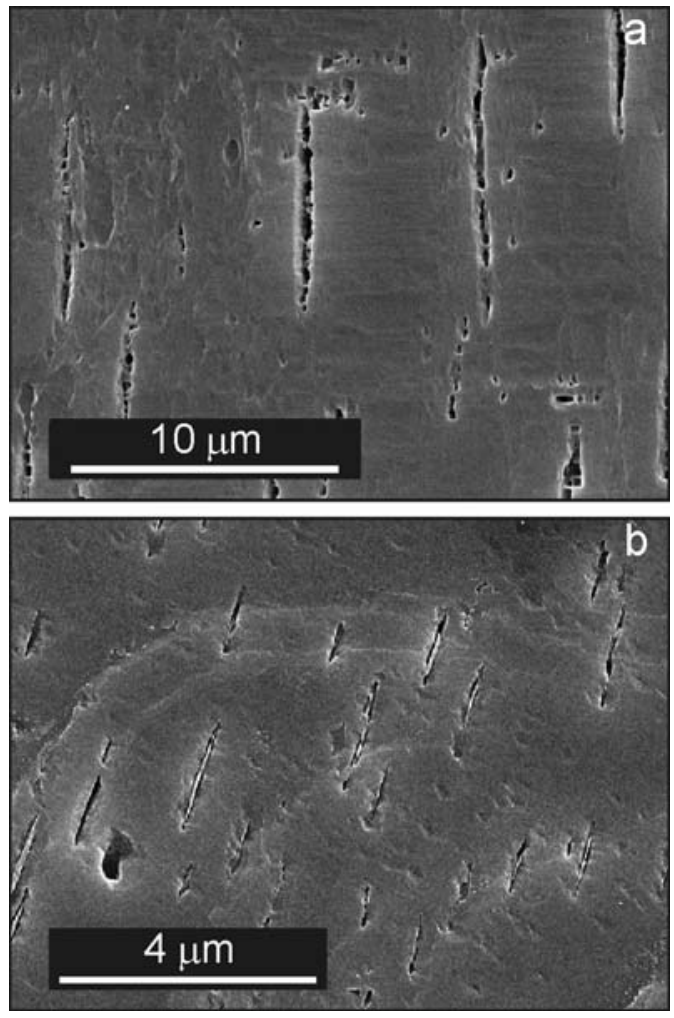

FIG. 4. Perth. SE images of HF etched (001) cleavage surface showing lenticular microperthitic albite lamellae parallel to b, enlarged by etching, in microcline. (a) Larger albite lamellae, considerably dissolved, with etch pits probably developed on misfit dislocations. The sample is somewhat over-etched, but their periodic character can be seen in the lamellae at the left. (b) Field of very small lamellae. Albite lenses have dissolved rapidly at their interfaces because of coherency strain, but retain albite in their cores.

strains induced by Albite twins in the albite lamellae have led to the development of Albite and Pericline twinned microcline in the adjacent orthoclase matrix. It would be valuable to study this process at the TEM scale. Sánchez-Muñoz et al. (2012) provide LM and TEM micrographs of feldspars from a large number of pegmatites including some beautiful LM images of twinning in microcline, and HRTEM images illustrating the coherency of twins and albite films. Bright-field TEM images of fine-scale film lamellae show features in common with lamellae from the Shap granite, including, in our view, evidence that they have been modified in some cases by fluids (Lee

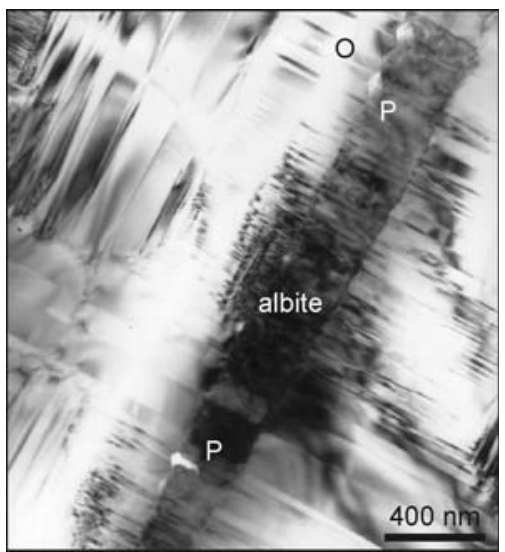

FIG. 5. Perth. Bright-field TEM image viewed parallel to the normal to (001). All subsequent TEM images are of this type and orientation. The field is mostly microcline, twinned below the scale of a light microscope on the Albite (top left to bottom right) and Pericline (top right to bottom left) laws. Note the large range of twin periodicities. A single Albite-twinned albite lamella is labelled, tapering towards the bottom of the micrograph. In places the albite has been replaced in a fluid (below the word 'albite') and the regular Albite twinning has been partly lost. Pores (P) have developed at the interface, and at the top outgrowths with the $\{001\}$ pericline habit have formed $(\mathrm{O})$.

et al., 1995; Lee and Parsons, 1997) but SánchezMuñoz et al. do not cite the Shap work and have reached several erroneous conclusions, which we discuss later.

Balić-Źunić et al. (2013) studied two samples of mesoperthitic feldspars from pegmatites associated with the Larvik syenite, from the Oslo province, Norway. Their SEM images show that one sample is a submicron-scale coherent film or 'braid' perthite, while the second is a ragged vein perthite on scales of $100 \mu \mathrm{m}$. The authors mistakenly interpret the difference in scale as being caused by differences in cooling rate, but the coarse intergrowth has been clearly produced by deuteric dissolution-reprecipitation. As we discuss later, intergrowths on $100 \mu \mathrm{m}$ scales cannot be produced by diffusion. A detailed analysis of Balić-Źunić et al.'s paper is given by Parsons et al. (2015). An LM example of partial deuteric coarsening of a feldspar from a larvikitic pegmatite was given by Parsons (1978, fig. 3). Some SEM images of the intergrowths in the present study were provided in a review by Parsons and Lee (2005). Here we develop our interpretation more fully in the light of new TEM work. 


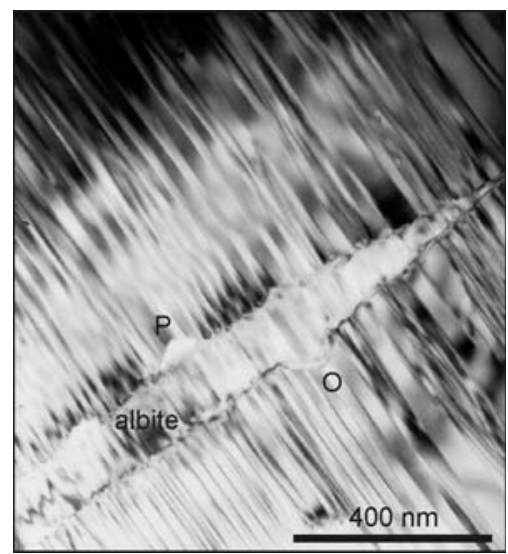

FIG. 6. Perth. TEM image of the wedge-shaped end of a cryptoperthitic albite lamella in Albite-twinned microcline. Albite twins in the albite have the same thickness as abutting twins in microcline, and the interface has zig-zag corrugations. This suggests that exsolution occurred after twinned microcline had formed. Larger, steeper zig-zag outgrowths $(\mathrm{O})$ grew subsequently by replacement and have the $\{110\}$ pericline habit. Pores $(\mathrm{P})$ have the same habit.

\section{Terminology}

We follow the conventions of Smith and Brown (1988). The abbreviations Ab, Or and An denote the feldspar components $\mathrm{NaAlSi}_{3} \mathrm{O}_{8}, \mathrm{KAlSi}_{3} \mathrm{O}_{8}$ and $\mathrm{CaAl}_{2} \mathrm{Si}_{2} \mathrm{O}_{8}$. The words albite, orthoclase and microcline refer to phases, not necessarily of endmember composition. The word orthoclase denotes an Or-rich feldspar phase with incomplete $\mathrm{Si}, \mathrm{Al}$ order and a 'tweed' microtexture, monoclinic using $\mathrm{X}$-ray and electron diffraction (although diffraction spots may be streaked). Microcline is more ordered, is triclinic in diffraction, and shows Albite and Pericline twinning combined in various ways usually described as 'tartan' twinning (Smith and Brown, 1988, p. 541). This is sometimes the variety called 'irregular microcline' by Bambauer et al. (1989). Orthoclase and microcline often occur together within 'single crystals', sometimes with sharp interfaces (e.g. Waldron et al. 1993, fig. 2), sometimes with gradational boundaries (e.g. Fitz Gerald and McLaren 1982, fig. 11). Names of twin laws are capitalized. Miller symbols of planes and forms all relate to the macroscopic $C 2 / m$ symmetry of the crystals, not to the $C \overline{1}$ symmetry of twins in the albite and microcline phases. The composition plane of Albite twins in both albite and microcline is (010), that of Pericline twins is an irrational plane

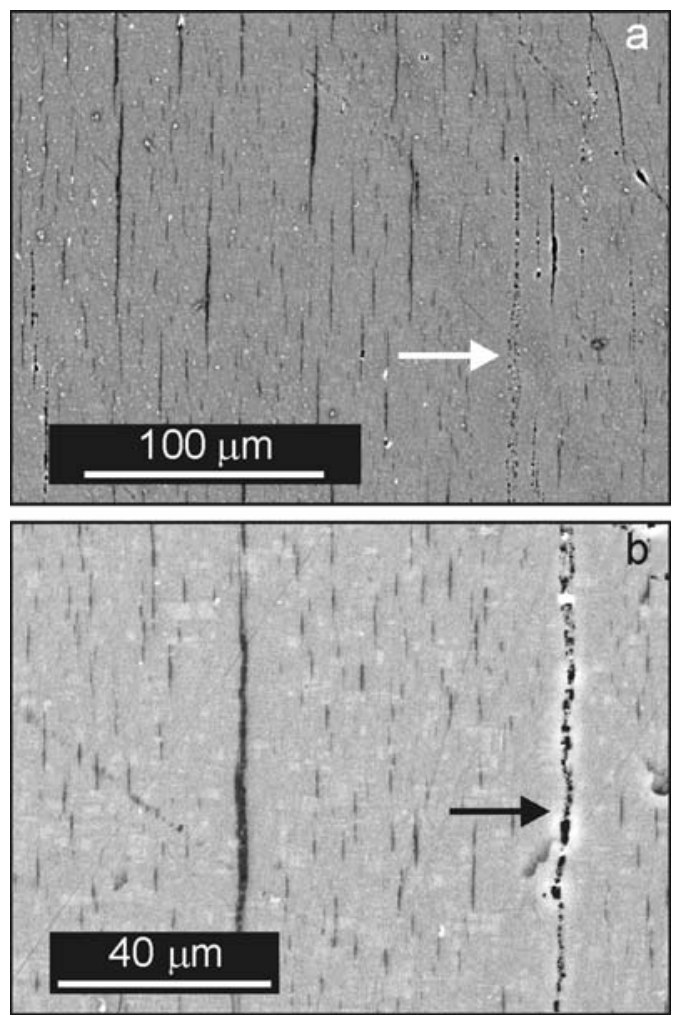

FIG. 7. Perth. BSE images (polished section) of microand crypto-perthitic albite lamellae (dark grey) parallel to b in microcline. (a) Note the very large range of scales. Some lamellae have been dissolved naturally, leaving lines of pores, and a thick lamella at the right (arrowed) is represented by lines of pores but is filled by material with no Z-contrast with microcline (compare Fig. 8). (b) Similar image at higher magnification. A thick lamella at the right has been replaced by a line of pores. The tartan twinning of microcline can be discerned faintly in the matrix, presumably an effect of orientation.

parallel to $b$, about which it rotates depending on feldspar composition and $\mathrm{Si}, \mathrm{Al}$ order. In low microcline it is almost at right angles to (001) and in low albite almost at right angles to (100). All micrographs in this paper are of sections approximately parallel to the (001) cleavage, so that microcline shows 'tartan' twinning, while only Albite twins are visible in albite. The low- $T$ variety of albite with the $\{110\}$ habit is called pericline (not capitalized). The equivalent $\mathrm{K}$-feldspar is adularia. Sub-grains with the adularia or pericline habit are characteristic of replacement in feldspars (Worden et al., 1990; Walker et al., 1995; Parsons and Lee, 


\section{PERTHITES FROM PEGMATITES}

2009; Parsons et al., 2013). The terms macro-, micro- and crypto-perthite refer to intergrowths which are visible unaided, in a light microscope, and below the resolution of a light microscope, respectively, usually in conjunction with Andersen's (1928) 'film' and 'vein' terminology. The terms perthite, mesoperthite and antiperthite, which reflect the bulk composition of the feldspar, are used as suggested by Parsons (2010, fig. 1.3).

Perthites formed by replacement are usually several orders of magnitude coarser than film perthites (Parsons and Brown, 1984). Both types of intergrowth occur in the feldspars described here. Replacement perthites are morphologically irregular. If the albite:K-feldspar ratio is high they may have a 'patch' morphology viewed from near the normal to (001) (e.g. Worden et al., 1990; Parsons and Lee, 2009) but crystals with more $\mathrm{K}$-feldspar usually contain ragged sheets, or lenses of variable aspect ratio, with irregular surfaces orientated overall near (100) or $\{110\}$. Andersen (1928) called these 'vein perthite'.

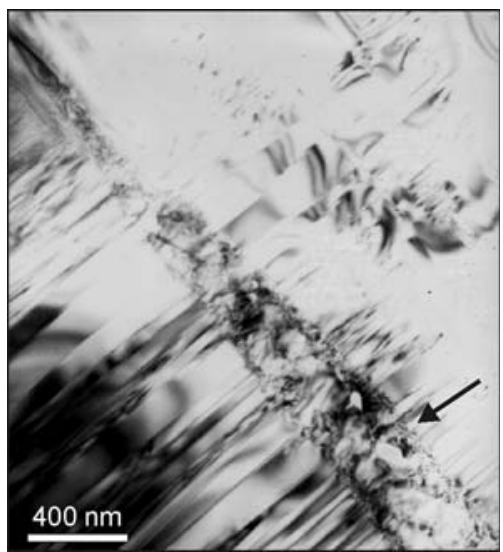

FIG. 8. Perth. TEM image of a wedge-shaped crypto-lamella in which albite has been largely replaced by subgrains of irregular microcline. It is therefore a lamella of irregular microcline in regular, Albite twinned microcline, and arguably not a perthite. Some of the subgrains have the $\{110\}$ adularia habit (arrow). There are also numerous micropores (white), some with the same habit.

TABLE 1. Chemical Composition of pegmatitic alkali feldspars from Perth, Ontario and Keystone, South Dakota

\begin{tabular}{|c|c|c|c|c|c|}
\hline & \multirow{2}{*}{ Size fraction } & \multicolumn{3}{|l|}{ Mol.\% } & \multirow{2}{*}{$n$} \\
\hline & & Or & $\mathrm{Ab}$ & An & \\
\hline \multicolumn{6}{|l|}{ Perth microcline macromesoperthite } \\
\hline \multirow{2}{*}{\multicolumn{2}{|c|}{ Bulk analyses (Hunt, 1851), probably of type sample M2361 }} & 41.4 & 54.9 & 3.7 & \\
\hline & & 40.9 & 56 & 3.1 & \\
\hline & Mean & 41.2 & 55.5 & 3.4 & \\
\hline \multirow[t]{4}{*}{ Bulk analysis of powders (Holdren and Speyer, 1987) ${ }^{1}$} & $<30 \mu \mathrm{m}$ & 55.7 & 43.7 & 0.6 & \\
\hline & $50-100 \mu \mathrm{m}$ & 58.9 & 40.5 & 0.6 & \\
\hline & $200-400 \mu \mathrm{m}$ & 57.6 & 41.7 & 0.7 & \\
\hline & Mean & 57.4 & 42.0 & 0.6 & \\
\hline $\begin{array}{l}\text { Microcline with included micro- and crypto-perthitic } \\
\text { film albite lamella } e^{2}\end{array}$ & & $92.8(4.0)$ & $7.2(4.0)$ & 0.0 & 10 \\
\hline Replacive albite veins & & $0.6(0.1)$ & $99.2(0.1)$ & $0.2(0.0)$ & 5 \\
\hline \multicolumn{6}{|l|}{ Keystone microcline microperthite } \\
\hline \multirow[t]{4}{*}{ Bulk analysis of powders (Holdren and Speyer, 1987) ${ }^{1}$} & $<30 \mu \mathrm{m}$ & 77.9 & 21.2 & 0.9 & \\
\hline & $50-100 \mu \mathrm{m}$ & 78.8 & 20.1 & 1.1 & \\
\hline & $200-400 \mu \mathrm{m}$ & 78.3 & 20.8 & 0.9 & \\
\hline & Mean & 78.3 & 20.7 & 1.0 & \\
\hline $\begin{array}{l}\text { Microcline with included micro- and crypto-perthitic } \\
\text { film albite lamellae } e^{2}\end{array}$ & & $94.3(1.2)$ & $5.7(1.2)$ & 0.0 & 12 \\
\hline Replacive albite veins & & $0.4(0.1)$ & $99.6(0.1)$ & 0.0 & 3 \\
\hline
\end{tabular}

\footnotetext{
${ }^{1}$ Holdren and Speyer give analyses for three grain size fractions.

${ }^{2}$ Averages of electron probe analyses (standard deviation in brackets) using an electron beam rastered over a $10 \mu \mathrm{m}$ square.

$n=$ number of analysed areas.
} 


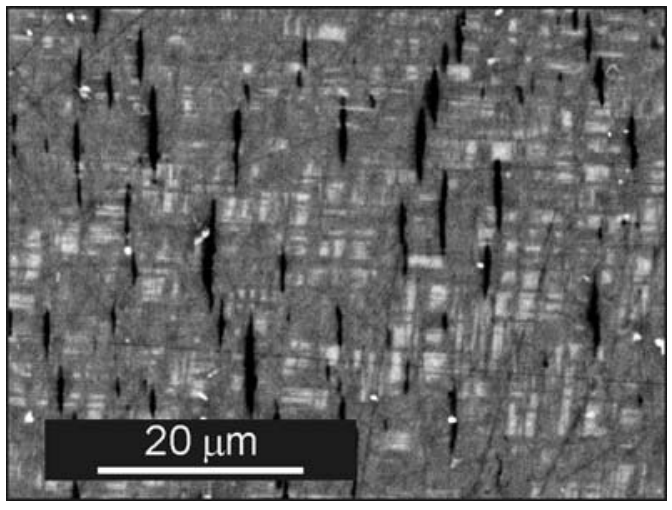

FIG. 9. Perth. CL image using SEM, polished thin section, of a region with microperthitic lamellae. Lamellae are non-luminescent because the albite has been completely dissolved away naturally, leaving lens-shaped pores.

Tartan twinning is visible in the matrix microcline.

Turbidity in alkali feldspars is caused by large numbers of $\mu \mathrm{m}$-scale micropores that form at the junctions between the incoherent subgrain mosaics of which replacement perthites are composed (Worden et al., 1990; Walker et al., 1995). Some replacive perthites form from coherent film perthite by replacement that is isochemical with respect to the main feldspar components in the bulk crystal and is driven by decrease in coherency strain energy. This process was called 'mutual replacement' by Smith and Brown (1988). The mechanisms of mutual replacement in feldspars from the Klokken syenite intrusion have been studied in detail at the EM scale by Worden et al. (1990), Walker et al. (1995), Parsons and Lee (2009), Parsons et al. (2009, 2013). Recently, Norberg et al. (2013) have for the first time successfully produced coarse patch perthites from a coherent cryptoperthitic intergrowth in the laboratory. They reacted a synthetic cryptoperthite with $\sim 20 \mathrm{wt} . \%$ water or $0.1 \mathrm{M} \mathrm{HCl}$ at 1 and $1.5 \mathrm{GPa}$ at up to $500^{\circ} \mathrm{C}$ for 4 days. Replacement was not observed in runs at 200 and $400 \mathrm{MPa}$. Although the amount of fluid used and the $P$ in these experiments are higher than is likely in many natural circumstances, the similarity between the experimental microtextures and natural patch perthites is striking.

Replacement is often not isochemical but in coarse replacement perthites laborious electron microprobe (EPMA) traversing is needed to establish whether an original bulk composition has been retained (e.g. Brown et al., 1983). Replacement that is not isochemical with respect to the major feldspar components in the bulk crystal was unambiguously demonstrated in feldspars from the Shap granite (Lee and Parsons, 1997), and we show below that the same conclusion can be reached for Perth and Keystone.

\section{Methods}

Polished thin sections of all of the samples were characterized by LM (Figs 1, 2, 15a). The Wards samples were examined using a Philips XL30 CP SEM operated at $20 \mathrm{kV}$. Images were formed using secondary electrons (SE), backscattered electrons (BSE) and CL detectors. Specific areas of the crypto- and micro-perthitic microcline matrix in the Perth sample were analysed chemically using a Cameca Camebax electron probe operated at $15 \mathrm{kV}$. The electron beam was rastered over $10 \mu \mathrm{m}$ squares to minimize $\mathrm{Na}$ loss and to provide bulk analyses of cryptoperthitic regions, and data were quantified using an on-line $P A P$ correction procedure. The albite lamellae included in these analyses are of variable and irregular distribution (Figs 4, 7, 17) and the size of the rastered areas relative to the lamellae accounts for the large standard deviation given in Table 1. The mean analyses given are likely to represent a good estimate of the local bulk composition of the microcline before coherent exsolution occurred.

To characterize microtextures at scales between BSE SEM and TEM imaging, (001) cleavage fragments were etched with $\mathrm{HF}$ acid vapour as described by Waldron et al. (1994), and examined using SE in the SEM. Etching is a useful method for distinguishing Or-rich feldspar from albite (Or-rich feldspar etches more rapidly) and for revealing dislocations and nanotunnels (Fitz Gerald et al., 2006) which etch to form discrete pits. Selected areas were prepared for TEM by gluing copper discs with a central hole $0.4-0.8 \mathrm{~mm}$ in diameter to the surface of the thin sections. The discs were then extracted and ion thinned until electron-transparent using an Atom Tech 700 thinner. The thinned foils were examined using a Philips Biotwin TEM operated at $120 \mathrm{kV}$.

\section{Samples}

Two of the samples of the pegmatitic alkali feldspars described here were acquired from Wards Scientific. As we note in the Introduction this is because they have been used previously in work on feldspar dissolution and anomalous TL fading. The sample of 'Perth perthite' (Wards catalogue 46 E 0510) comes from near 
Perth, Ontario, Canada and 'Keystone microcline' (Wards 46 E 5125) is from the Black Hills, South Dakota, USA. Because these feldspars were purchased their exact geological setting is unknown, although the size of the fragments (several $\mathrm{cms}$ ) demonstrates that they are from pegmatites. For brevity we refer to these samples as Perth and Keystone. Perth has a vivid pink colour and is perthitic to the unaided eye, in shades of pink. It is cut by narrow bands of quartz. A colour photograph was given in Parsons and Lee (2005, fig. 7c). Holdren and Speyer (1987) determined the bulk chemical composition of three different grain sizes of powders of Perth and Keystone obtained from Wards (Table 1). The bulk composition of Perth is $\mathrm{Or}_{57.4} \mathrm{Ab}_{42.0} \mathrm{An}_{0.6}$ (Table 1). It is therefore strictly a microcline macromesoperthite.

Keystone is overall white in colour, with clear areas transected by turbid bands, many of which are approximately parallel to $\{110\}$. It is not visibly perthitic in hand specimen and is a microcline microperthite, bulk composition $\mathrm{Or}_{78.3} \mathrm{Ab}_{20.7} \mathrm{An}_{1.0}$, (Table 1). An informative description of pegmatites in the Keystone district was given by Orville (1960).

The matrix microcline in both Perth and Keystone is itself cryptoperthitic. Electron probe analyses of the macro- and micro-perthitic replacive albite, and of the bulk composition of the microcline matrix with its included micro- and crypto-perthitic albite lamellae, are given in Table 1. We presume that both samples grew as sanidine, and passed through a stage when a tweed orthoclase texture developed, before ordering to microcline, although there is no direct evidence for this. The character of the orthoclasemicrocline transition is discussed by Smith and Brown (1988), Brown and Parsons (1989) and Carpenter and Salje (1994).

\section{Note on the type perthite}

Perth, Ontario, is the type locality of perthite (Thomson, 1843; Hunt, 1851) and we have compared Wards catalogue 46 E 0510 from Perth with a large cleavage fragment of feldspar (Hunterian M2361) which is believed to be from the type perthite. It is likely that the muchemployed Wards material comes from the same general locality as the type perthite, but it is not identical to M2361. This was discovered by Dr. James Wilson, who was born in the village of Douglas, in Lanarkshire, Scotland. Wilson graduated as a medical doctor from Edinburgh University in 1818, immigrated to Canada and settled in the village of Lanark, Ontario, moving shortly after to Perth. An enthusiastic amateur mineralogist and geologist, he sent his sample to Thomas Thomson, Regius Professor of Chemistry at Glasgow University, who gave it the name 'perthite' (Thomson, 1843). The local museum in Perth has a display of the type material and an account of Wilson's work. M2361 is a darker colour than the Wards material and it can be seen more easily by the unaided eye to be a mm-scale intergrowth of two feldspars, in roughly equal proportions. The matrix material is deep reddish brown, and contains somewhat sinuous lenses, parallel to $\mathbf{b}$, of a second feldspar, in a lighter shade of pink. Unfortunately, confusion was introduced by Thomson, who described his sample as white in colour and consisting of "...a mass of crystals so united together as to form a kind of tessellated pavement". His analysis showed no potassium or sodium, but consisted of 76 wt. $\%$ silica, $11.75 \%$ alumina and $11 \%$ magnesia!

T.S. Hunt, Chemist and Mineralogist to the Geological Survey of Canada, realized that Thomson's work was unreliable "owing to an unfortunate want of precision in his mineralogical descriptions" and re-described the perthite from Perth (Hunt, 1851). His sample was "light fleshred, alternating with reddish or pinchbeck brown, the two colours forming bands from half a line to a line in width, coincident with one of the planes $\mathrm{T}$, often however interrupted and intermingled one with another. The darker bands on the cleavage surface $\mathrm{T}$ exhibit, when viewed perpendicularly, a golden reflexion like the variety known as aventurine felspar". This description applies in all respects to our fragment of M2361.

In thin section (not available to Hunt) M2361 is a vein perthite with albite forming periodically distributed lenticular sheets, overall parallel to $\mathbf{b}$ (Fig. 1a), but locally slightly oblique (Fig. 1b). At low power, lamellae appear relatively smooth-sided (Fig. 1a), although in detail the interfaces are serrated (Fig. 1b). The surfaces of the lenses lack the extreme complexity of the albite veins in Wards $46 \mathrm{E} 0510$ (Figs 2b, 3). The average periodicity of the lenses is $\sim 0.5 \mathrm{~mm}$. The albite has a pronounced $\{110\}$ cleavage (Fig. 1a), and in places a second feldspar, presumably microcline, forms thin $\{110\}$ plates partially outlining albite subgrains (Fig. 1b). In some regions the lenses adopt a more nearly equidimensional, globular shape, and there are also regions in which thick albite lamellae are missing. Fine-scale, film microperthite occurs in these regions. Most of the microcline has very regular, straight-sided tartan twinning (Figs 1b,c), with 
occasional regions of coarser twinning. It forms a matrix to the albite films, and is crowded with tiny euhedral plates of orange-brown biotite, most abundant in the central parts of the microcline lamellae (Fig. 1b). This suggests that the formation of biotite was related to the replacement process that produced the macroperthite. The plates of biotite have no visible effect, at the LM scale, on the tartan twinning (Fig. 1c). The biotite presumably accounts for the dark brown colour of the microcline in this sample and also the golden schiller noted by Hunt and visible in our fragment. The albite has fine-scale Albite twinning, varying in thickness, and sometimes showing lateral off-sets suggesting deformation or the presence of subgrains.

Hunt's two analyses (1851) correspond with a bulk composition of $\mathrm{Or}_{41.2} \mathrm{Ab}_{55.5} \mathrm{An}_{3.4}$ (Table 1), more albitic than the Ward's sample; the proportions of the phases in thin section suggest a predominance of albite. We conclude that although they are likely to have come from the same general locality, the Wards sample described in the present paper is not the type material.

\section{Microtextures: Perth}

In thin section, Perth (Wards catalogue 46 E 0510) is a macromesoperthite composed of ragged veins, lenses and patches of Albite-twinned albite, up to a few $\mathrm{mm}$ in width, enclosed within microcline with very finescale $(\sim 1 \mu \mathrm{m})$ regular cross-hatched twinning (Fig. 2). The microcline contains micro- and crypto-perthitic film albite lamellae typically $\sim 200 \mathrm{~nm}$ thick (Figs 29). The bulk composition given by Holdren and Speyer (1987) $\left(\mathrm{Or}_{57.4} \mathrm{Ab}_{42.0} \mathrm{An}_{0.6}\right.$, Table 1), has more An than either the bulk composition of the microperthitic microcline or the composition of the macroperthitic albite veins obtained using EPMA (Table 1). This suggests that Holdren and Speyer's powders contained small amounts of a Ca-bearing impurity, perhaps carbonate. Nevertheless their analysis of a crushed bulk sample is a reliable estimate of the bulk composition of the whole intergrowth. The albite forms veins predominantly parallel to (100), but with complex surfaces. Irregular patches also occur, and albite areas are sometimes visibly composed of subgrains (Fig. 2a). The microcline is mostly non-turbid in both samples, but the microperthitic film lamellae are often relatively turbid, making them more prominent under light microscopy. BSE images (Fig. 3) show remarkable, complex boundaries to the macroperthite, and the contrastingly regular microperthite lamellae in the microcline matrix. For reasons given below we believe that the macroperthite formed by large-scale replacement, and the fine-scale microtextures by diffusion. The latter are described first.

\section{Perth: crypto- and micro-perthitic microcline}

The microcline with its included crypto- and microperthitic albite has a bulk composition of $\sim \mathrm{Or}_{92.8} \mathrm{Ab}_{7.2}$ (Table 1). Ca was below detection using the microprobe. SEM images of etched (001) cleavage surfaces (Fig. 4) and BSE images (Figs 3,7 ) show albite exsolution lamellae with a large range of lengths, from $<1$ up to $100 \mu \mathrm{m}$ and maximum thicknesses from a few nm to several $\mu \mathrm{m}$. They are orientated parallel to $\mathbf{b}$ in (001) sections. A micrograph from Laves and Soldatos (1963, fig. 1, reproduced in Smith, 1974, fig. 19-4a) which appears to be of a sample similar to Wards $46 \mathrm{E}$ 5125 , shows that overall the macroperthite lies in $\sim(100)$, while the microperthitic lamellae lie in $\sim(\overline{6} 01)$. On etched surfaces (Fig. 4) thicker lamellae are straddled or cut by etch pits. These pits form in pairs at sites where misfit edge dislocation loops encircling the albite lenses intersect the cleavage surface, and demonstrate that the lamellae are semicoherent. Contrary to the interpretation of Sánchez-Muñoz et al. (2012, their fig. 14) dislocations develop during coherent coarsening at $T$ well below the $C 2 / m-C \overline{1}$ shearing transformation in albite, when twinning first appears (see Brown and Parsons, 1984b). Unlike the semicoherent lamellae in an orthoclase matrix imaged by Lee et al. (1995, figs 2, 3, 4) and by Fitz Gerald et al. (2006, fig. 1) the lamellae in Figs 4-7 do not have smooth surfaces. In feldspars from other localities (Fitz Gerald et al., 2006) structure around misfit dislocations has been dissolved away during fluid-rock reactions to produce nanotunnels with diameters of a few $\mathrm{nm}$, and this is likely to be the case in Perth.

The TEM images show that the microcline is tartan-twinned on scales below that of a light microscope with twin thicknesses ranging from 200 to $<20 \mathrm{~nm}$ (Figs 5,6,8). Presumably, the twins visible in Fig. 2 are regions where a preponderance of fine-scale twins share a common orientation in a 'right-' or 'left'-handed sense, as suggested by Fig. 2c. The continuity of Albite and Pericline twins over long distances $(>400 \mu \mathrm{m})$ suggests that there is no underlying subgrain microtexture. Albite exsolution lamellae (Fig. 6) have wedge-shaped ends (Brady, 1987) and are Albite twinned with a 


\section{PERTHITES FROM PEGMATITES}

periodicity matching the local periodicity of Albite twins in the microcline. Twin periodicities in the albite are dictated by the enclosing microcline, indicating that it was already twinned when coherent exsolution began. Albite twins that form during exsolution in an untwinned matrix adjust their periodicity as coarsening proceeds, to minimize elastic strains (Willaime and Gandais, 1972 and see Brown and Parsons, 1988, for examples), but twin periodicities in the present case have been inherited clearly from an already twinned microcline precursor. This is not always the case. Sánchez-Muñoz et al. $(2008,2012)$ provide light micrographs of the development of tartan microcline twins forming selvages adjacent to thick lenticular albite veins near (100) in otherwise featureless K-feldspar (orthoclase?) in pegmatitic feldspars. In this case, longrange strains induced by Albite twin lamellae in albite have induced ordered regions with 'left' and 'right' orientation (twins) in an original tweed microtexture.

Locally the interface between individual albite lamellae and microcline in the Perth sample has a zig-zag form, alternately parallel to $\sim(130)$ and $\sim(130)$ (Fig. 6). It is this zig-zag surface that accounts for the roughness of lamellar interfaces seen using SEM. Isolated micropores, with the characteristic $\{110\}$ adularia habit (Worden et al., 1990; Walker et al., 1995) have sometimes developed (Figs 5, 6). Some of the exsolution lamellae have been partially replaced by albite which has euhedral outgrowths with the corresponding pericline habit. The sanidine-microcline transformation is usually placed at $500-480^{\circ} \mathrm{C}$ (Brown and Parsons 1989; Kroll et al. 1991) consistent with film exsolution at low- $T$ (see later). The extended exsolution lamellae (up to $100 \mu \mathrm{m}$, Fig. 6) and the continuity of twins in microcline show that, in contrast to Keystone (see later), Perth microcline is not a mosaic of subgrains.

A few cryptoperthitic and microperthitic lamellae in BSE images have no $Z$-contrast with the microcline (Fig. 7, arrowed) and are marked only by lines of pores. TEM (Fig. 8) shows that these lamellae are composed of subgrains of irregular microcline with micropores at their junctions. This intergrowth, of lamellae of irregular microcline in a more-regularly tartan-twinned microcline matrix, is not strictly a perthite. Similar intergrowths were reported by Lee and Parsons (1998) in detrital igneous feldspars undergoing diagenesis. In other regions albite in small lamellae has been completely dissolved, leaving lenticular pores (Fig. 9).

\section{Perth: vein macroperthite}

The albite veins (Figs 2, 3) are orientated approximately parallel to (100), are typically $\sim 0.6 \mathrm{~mm}$ wide and are spaced $\sim 1 \mathrm{~mm}$ apart in the cryptoperthitic microcline matrix. The albite is of near end-member composition $\left(\sim \mathrm{Ab}_{99.2}\right.$, Table 1$)$. The interface of the veins with host microcline is intricately serrated owing to the development of euhedral outgrowths of albite. The complex interfaces are strongly reminiscent of the fractal Mandelbrot set (Fig. 3). The turbidity of the albite and the microcline is similar and not unusually intense, but is most pronounced near the interfaces of veins. The least turbid areas of albite have the thickest Albite twins and some nonturbid subgrains are untwinned. CL images (Fig. 10) show that the albite outgrowths are zoned, the outermost $\sim 0.05 \mathrm{~mm}$ often being nonluminescent. Microcline immediately adjacent to the veins luminesces more brightly than in surrounding areas. The gradational changes in luminescence suggest a diffusion profile, perhaps in a trace element, but we do not know its source. There is no corresponding change in grey-scale in BSE SEM images (Fig. 3) when contrast depends essentially on $\mathrm{Na}$ and $\mathrm{K}$ distribution.

The albite veins are composed of slightly misaligned subgrains at the scale of 100s of $\mu \mathrm{m}$ (Fig. $2 a$ ). Albite twins range considerably in thickness and many are laterally discontinuous and wedge out. Some of the twins have developed from subgrain boundaries. TEM images (Fig. 11) show that Albite twins sometimes define steps in the microcline-albite interface. There is localized coherency strain and dislocation arrays along the immediate interface between albite films and microcline, which is clearly semicoherent. Similar sets of periodic dislocations were found by Norberg et al. (2011) at interfaces between albite and orthoclase produced during laboratory albitization experiments, and were reported by Lee and Parsons (1997, Fig. 4) along natural replacive albite-orthoclase interfaces in feldspars from the Shap granite.

Sub-regularly to irregularly-spaced etch pits occur on HF etched surfaces where Albite twin composition planes (010) in albite intersect the (001) cleavage surface (Fig. 12). Albite twin composition planes are usually assumed to be fully coherent but clearly these are not. Some planes have many closely-spaced pits whereas others are free of pits or have a few that are irregularly and widely spaced. The triangular shape of the pits and their constant facing-direction along 
the twin plane shows that the dislocations are oblique to (001). Sometimes the line of pits along the composition plane has branched off and followed an oblique track into the interior of a twin (top left of Fig. 12). Unlike dislocations surrounding lenticular exsolution lamellae (Waldron et al., 1994) the dislocations do not crop out in pairs, so they do not represent sections through dislocation loops. The etch pits differ considerably in both size and shape on either side of a twin. On one side they may be relatively large and angular whereas on the other they are smaller and more rounded (Fig. 12). In both cases, however, each individual pit is symmetrical about (010). TEM images (Figs 13, 14) confirm that each etch pit has formed where highly strained crystal structure surrounding a dislocation on the Albite twin composition plane intersects the cleavage surface. In most cases the dislocations are associated with steps of a few $\mathrm{nm}$ in the composition plane. Some Albite twins wedge out laterally and these terminations are marked by a high concentration of dislocations (Fig. 14).

In addition to dislocation etch pits, narrow and shallow grooves occur on the etched surface of each twin (Fig. 12). Each groove is up to $\sim 3 \mu \mathrm{m}$ long by $\sim 0.1 \mu \mathrm{m}$ wide. The long axes of the grooves are orientated approximately parallel to $\{110\}$ albite but are present in only one orientation within any one twin. In adjacent twins the grooves are related by a mirror plane on (010), forming a 'herringbone' structure either side of the Albite twin composition plane. The grooves terminate at, and are parallel to, the 'leading' edges of triangular dislocation etch pits, particularly larger ones, and grooves change direction at these points. It

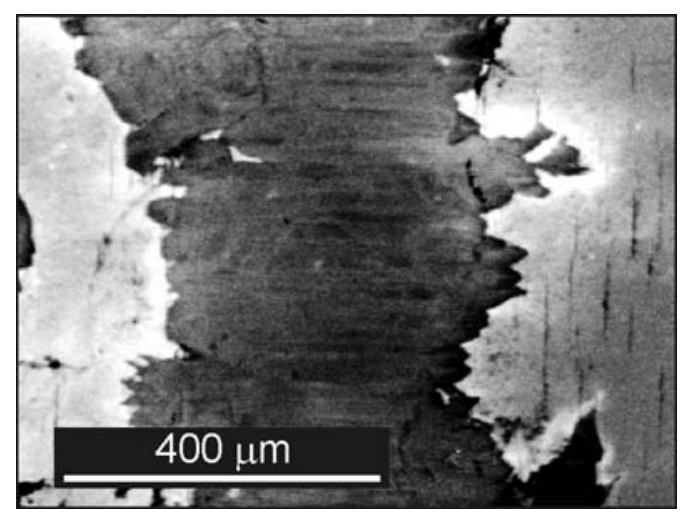

FIG. 10. Perth. CL image of macroperthitic albite lamella, same field as Fig. $3 b$. Albite twinning is faintly visible in the central region of the lamella.

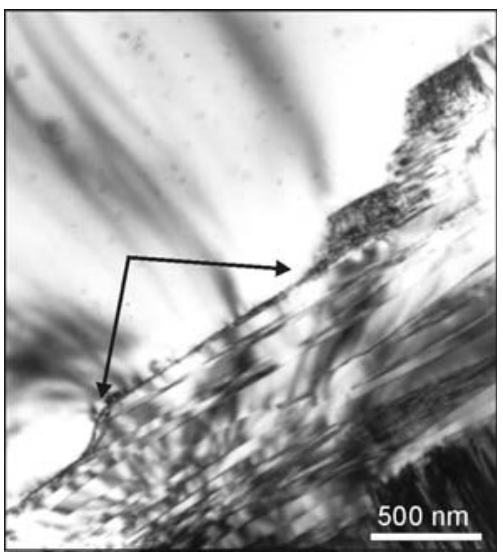

FIG. 11. Perth. Bright-field TEM image of a boundary of featureless macroperthitic albite (top left) against Albiteand Pericline-twinned microcline. The boundary is stepped at a variety of scales, and periodic strain shadows (between arrows) suggest it is semicoherent.

seems likely that the grooves result from increased dissolution in regions affected by long-range strains, but no strain contrast that could correspond with the grooves was observed in TEM images.

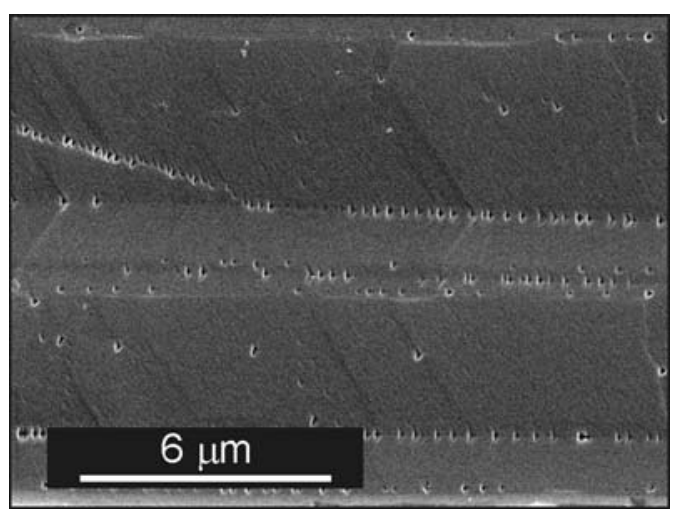

FIG. 12. Perth. SE SEM image of the HF-etched (001) cleavage surface of Albite- twinned albite in a macroperthitic albite vein. Triangular etch pits mark the outcrop of dislocations that are oblique to (001). Most decorate Albite twin composition planes although a few are unrelated and one set (top left) lies on an oblique feature. Note that the population of dislocations on either side of individual twins is different, and they do not occur in pairs like the misfit dislocations encircling strain-controlled albite exsolution lamellae. Note the alternating zig-zag shallow grooves in the twin surfaces. These terminate at, and are parallel to, the 'leading' edges of larger triangular dislocation etch-pits, suggesting they are related to long-range strains. 


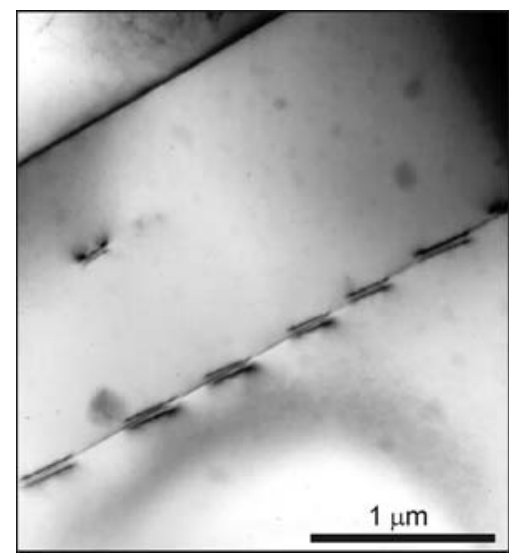

FIG. 13. Perth. Bright-field TEM image of inclined dislocations along an Albite twin composition plane in albite in a macroperthite. Each dislocation is associated with a tiny step (a few $\mathrm{nm}$ ) in the twin plane.

\section{Microtextures: Keystone}

Keystone has a bulk composition (Table 1) of $\sim \mathrm{Or}_{78} \mathrm{Ab}_{21} \mathrm{An}_{1}$, more Or-rich than Perth (Holdren and Speyer, 1987). In thin section (Fig. 15a) it is a vein microperthite with albite veins mostly in $\{110\}$, some in (100). The veins are more ragged and variable in thickness than Perth and the microperthite has no easily defined periodicity. In contrast with the regular, periodic, fine-scale tartan

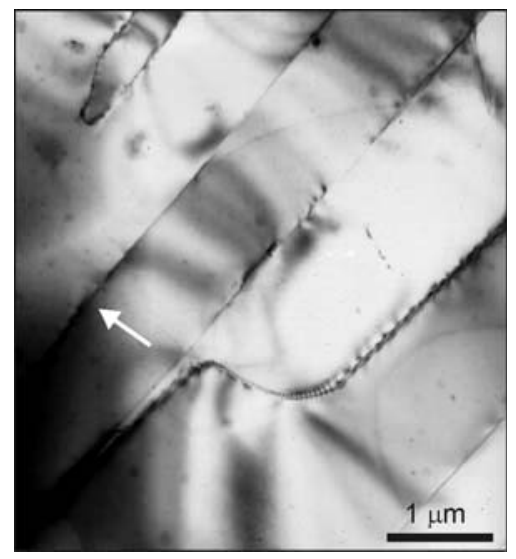

FIG. 14. Perth. Bright-field TEM image of tapered Albite twins in albite from macroperthitic film. The curved twin termination in the centre is marked by periodic strain shadows probably caused by dislocations. The tapered twin to the left of the arrow has steps along its composition plane. twinning of the Perth microcline, Albite and Pericline twins in Keystone vary considerably in thickness, reaching $\sim 100 \mu \mathrm{m}$ (Fig. 15a). They are markedly spindle-shaped in (001) section.

\section{Keystone: cryptoperthitic microcline}

The irregularity of the twin microtexture of the microcline is maintained at the TEM scale (Fig. 15b). In some areas the twins become diffuse and die away. Following Bambauer et al. (1989) the complex intergrowth would be described as 'irregular microcline'. Featureless areas are probably 'tweed' orthoclase although tweed is not visible at the magnification used. Unlike Perth there are well-defined subgrains with the $\{110\}-(010)$ adularia habit, with micropores at their junctions. Very similar microtextures occur in granites and syenites where perthite has been subject to replacive coarsening by dissolutionreprecipitation (Walker et al., 1995; Lee et al., 1995; Parsons and Lee, 2009; Parsons et al., 2013).

Like Perth, the Keystone microcline contains film crypto- and micro-perthitic lamellae (Figs 16, 17). The coarser microperthitic albite film lamellae are $\sim 0.1-0.25 \mu \mathrm{m}$ in thickness by $\sim 3-20 \mu \mathrm{m}$ in length and on etched surfaces are straddled by paired etch pits (Fig. 17a), demonstrating that they are semicoherent. The finer cryptoperthitic lamellae, $<0.1 \mu \mathrm{m}$ in thickness, are fully coherent. The Keystone film lamellae are both thinner and shorter than those in Perth, and we infer must be restricted to individual microcline subgrains. A coherent lamella could not pass across a subgrain boundary. Film lamellae post-dating subgrain formation in patch perthites have been described by Parsons and Lee (2009) and Parsons et al. (2013), and the kinetics of their formation has been discussed by Parsons and Fitz Gerald (2011).

Some of the semicoherent lamellae have been thickened by more than $10 \mu \mathrm{m}$ by the addition of albite in the form of euhedral outgrowths with the $\{110\}$ habit (Figs 17b,c). Local replacement leading to similar outgrowths is seen in the Shap granite (e.g. Lee et al., 1995; Lee and Parsons, 1997). As in Shap the Keystone late albite often contains 'ghosts' of the pre-existing film lamellae, and is clearly formed by replacement. Some semicoherent lamellae adjacent to fractures have been naturally dissolved, a feature also seen in Perth (Figs 6, 8).

Sánchez-Muñoz et al. (2012) provide TEM micrographs (their fig. 14) showing semicoherent film lamellae from a pegmatitic feldspar, in one case 

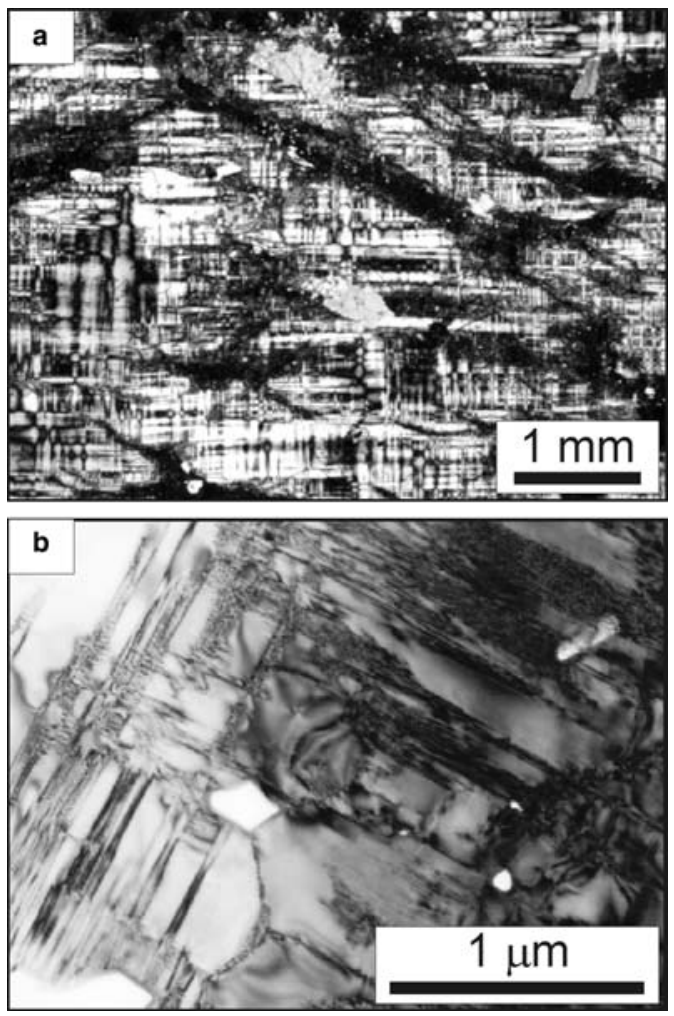

FIG. 15. Keystone. (a) Low-magnification light micrograph (crossed polarizers) showing microperthitic albite veins (at or near extinction) predominantly parallel to $\{110\}$ with short sections in (100). The microcline matrix shows Albite and Pericline tartan twins with a large range of scales and marked spindle shapes (compare with Fig. 1). (b) Bright-field TEM image of microcline showing variability in the thickness of Albite twins (running from bottom right towards top left) and Pericline twins (mostly at the left), down to the scale of a few $\mathrm{nm}$. Subgrains defined by $\{110\}$ and (010), with micropores at their edges (white), are visible in the lower centre. The right-hand part of the image is 'irregular microcline' as defined by Bambauer et al. (1989).

modified by development of what they call an 'albite diamond', that can be matched both in Keystone (Fig. 17) and in the Shap examples. However, they chose to interpret the formation of the 'diamonds' to be by a continuous, solid state diffusion process, and present (their fig. 21) a "schematic model for a general sequence of transformations in perthitic K-rich feldspar from granitic pegmatites" which makes no reference to replacement reactions at any stage. We think, as did Alling (1921), that microtextures

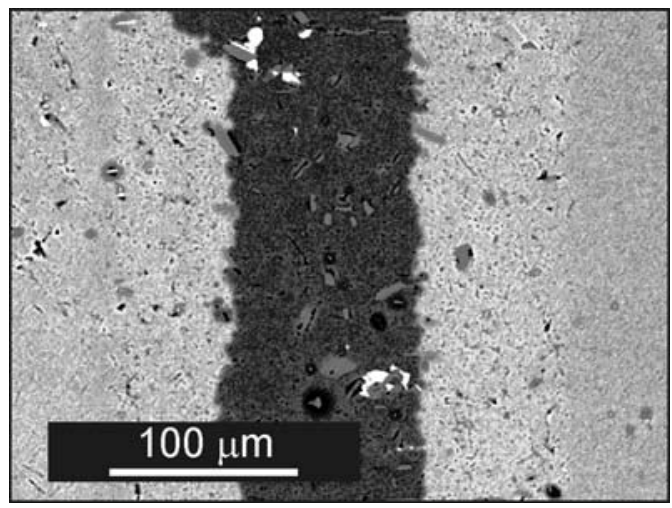

FIG. 16. Keystone. BSE image showing a coarse albite vein, overall parallel to $\{110\}$, in a cryptoperthitic microcline matrix. Lenticular cryptoperthite film lamellae are just visible in the matrix, parallel to average $\mathbf{b}$ in the microcline, running top right to bottom left, near the right and left edges of the micrograph. On either side of the vein is a $\sim 70 \mu \mathrm{m}$ wide zone with many micropores and flakes of sericite. Relics of the cryptoperthitic lamellae can be seen in the sericitized zone. Both this region and the vein contain irregularly orientated crystals of albite, and some crystals of quartz.

formed by replacement reactions are the norm in alkali feldspars from pegmatites and plutonic igneous rocks. The pervasive character of replacement is shown most clearly by the patch perthites of the Klokken syenite intrusion (Worden et al., 1990; Parsons and Lee 2009; Parsons et al., 2013) and by our work on the Shap granite (Lee et al., 1995; Lee and Parsons, 1997). The 'albite diamonds' of Sánchez-Muñoz et al. (2012) are, we believe, replacive subgrains with the $\{110\}$ adularia habit (e.g. present Fig. 17). This low- $T$ growth habit is a hall-mark of subgrains produced by replacement reactions in feldspars by deuteric fluids in igneous rocks (Worden et al., 1990; Walker et al., 1995; Lee and Parsons, 1997; Parsons and Lee, 2000, 2009; Parsons et al., 2013), during retrogression of high-grade metamorphic rocks (Waldron et al., 1993) and at near-surface $T$ during diagenesis (Lee and Parsons, 1998). It is hard to see how 'diamond' albite subgrains in figure $12 \mathrm{f}$ of Sánchez-Muñoz et al. (2012), which are chemically zoned in the ultraviolet using CL, could have grown by solid-state diffusion. Lee et al. (2007), Parsons et al. (2008) and Parsons and Lee (2009) have illustrated and discussed the complex, sometimes oscillatory zoning that can be observed in replacive subgrains using CL. 


\section{Keystone: vein microperthite}

The replacive albite lamellae (Fig. 15a) are nonperiodic, irregularly distributed, turbid and very variable in size, from $\sim 50$ to $400 \mu \mathrm{m}$ in thickness. The majority are veins at $\sim 60$ degrees to (100), close to $\{110\}$, but some veins are roughly parallel to (100). Albite in the veins is Albite-twinned and very close to end-member albite in composition ( $\mathrm{Ab}_{99.6}$, Table 1). Like, Perth, etch pits occur along Albite twin composition planes, but the veins have not been examined by TEM. The veins are discontinuous and often wedge-out, and have irregular surfaces (Fig. 16), although not as complex as Perth (Figs $2,3,10)$. The microcline in their vicinity has been extensively altered to sericite (Fig. 16), and both vein and matrix contain inclusions of quartz and abundant blocky inclusions of Albite-twinned albite, a few tens of $\mu \mathrm{m}$ in size. These plagioclase inclusions have no fixed crystallographic orientation relative to the microcline.

\section{Development of strain-controlled microtextures}

Perth and Keystone both have two distinct microtextures: (1) a largely pristine microcline matrix, containing strain-controlled coherent and semicoherent film micro- and crypto-perthitic albite lamellae and (2) relatively irregular, thick, largely incoherent albite veins, near (100) in Perth and predominantly near $\{110\}$ in Keystone. LM work by Andersen (1928) demonstrated that these two types of microtexture commonly coexist in alkali feldspars from granite pegmatites, as they do in feldspars from granites (e.g. Lee et al., 1995).

The strain-controlled exsolution microtextures (Figs 4-7, 17a) formed during cooling by volume diffusion following nucleation at or below the coherent solvus in chemically homogeneous but tartan-twinned microcline (Figs 5,6) with a bulk composition of $\mathrm{Or}_{93-94} \mathrm{Ab}_{7-6}$. Spinodal decomposition can be ruled out as an exsolution mechanism for compositions far from the solvus critical composition because the coherent spinodal is then at very low $T$ (see discussion in Parsons and Brown, 1991). Parsons et al. (2010, their fig. 1) published a compilation of relevant binary Ab-Or solvus curves that can be used to estimate $T$ directly because in the present case bulk An was below detection (Table 1). Because of the Or-rich bulk composition of the microcline, exsolution began at low $T$ (see below) and this has led to film lamellae in the pegmatitic alkali feldspars that are considerably finer-scale than those typical of many granites (compare with the Shap Granite, Lee et al., 1995, bulk $\sim \mathrm{Or}_{70}$ ). During further cooling the lamellae coarsened and misfit dislocations nucleated on the coarser lamellae to minimize coherency strain energy as the crystal structure stiffened. The development of misfit dislocations is very common in $\mathrm{K}$-feldspars with fine film perthite lamellae (see e.g. Parsons and Lee, 2005; Parsons et al., 2005; Fitz Gerald et al., 2006; Parsons et al., 2013).

We can make rough, order of magnitude estimates of the $T-t$ evolution of these semicoherent intergrowths. It must be stressed that $T$ and kinetic estimates in this section require long extrapolations in both $T$ and $t$ from existing experimental work. A minimum growth $T$ for a homogeneous microcline $\mathrm{Or}_{93} \mathrm{Ab}_{7}$ can be estimated by extrapolation of a strain-free solvus for equilibrium order inferred by Brown and Parsons (1984a), which at low $T$ corresponds with an extrapolation of the strainfree ordered solvus of Bachinski and Müller (1971). The $P$-dependence of the solvus is known only for disordered feldspars on the strain-free solvus and is $220 \mathrm{~K} \mathrm{GPa}^{-1}$ (Hovis et al., 1991). If the microcline grew with equilibrium order this curve implies growth at or above $\sim 400^{\circ} \mathrm{C}$ at $0.1 \mathrm{GPa}, \sim 490^{\circ} \mathrm{C}$ at $0.5 \mathrm{GPa}$ and $710^{\circ} \mathrm{C}$ at $1.5 \mathrm{GPa}$.

Coherent nucleation followed by coarsening will have begun at $T$ at or a little below a coherent solvus curve (which is at $T$ below the strain-free solvus) for feldspars with an ordered framework. Yund (1974) provided such a solvus curve for $T>450^{\circ} \mathrm{C}$, which Parsons et al. (2010, fig. 1) extrapolated to $300^{\circ} \mathrm{C}$ using a polynomial. The solvus is extremely steep at low $T$ but $\mathrm{Or}_{93}$ lies on a further extrapolation of this curve to $\sim 90^{\circ} \mathrm{C}$ at $0.1 \mathrm{GPa}, \sim 180^{\circ} \mathrm{C}$ at $0.5 \mathrm{GPa}$ and $\sim 400^{\circ} \mathrm{C}$ at $1.5 \mathrm{GPa}$, assuming that the $P$ dependence recommended by Hovis et al. (1991) can be applied. We do not know the $P$ at which the Perth pegmatite crystallized and in a protracted geological history it is possible that the pegmatite was subsequently buried more deeply. Whatever the $P$, coarsening kinetics below $200^{\circ} \mathrm{C}$ are too slow to have produced the observed lamellar periodicities (see Fig. 18 and next paragraph). We can be confident that exsolution and coarsening began at $\leq 400^{\circ} \mathrm{C}$, with misfit dislocation formation at some lower $T$.

We can consider the kinetics of lamellar exsolution at low $T$ in the light of experimental work. The most complete experimental data describing coherent coarsening in cryptoperthites are those of Yund and Davidson (1978). They annealed a disordered homogeneous alkali feldspar 
starting material, $\mathrm{Ab}_{65} \mathrm{Or}_{35}$, at $560-470^{\circ} \mathrm{C}$, without water for time $(t)$ up to $1.5 \mathrm{y}$ and measured the periodicity $(\lambda)$ of the film cryptoperthite that developed, using TEM. This annealing method provides the most realistic way to approach natural exsolution by diffusion because it includes the effect of coherency strain. However, the largest value of $\lambda$ produced experimentally was $46 \mathrm{~nm}$ so that extrapolation to the $\mu \mathrm{m}$ scale of our samples (Figs $3 a, 15 a$ ) is extremely large, and coherent exsolution began in our present samples at much lower $T$. Yund and Davidson also maintained an initially homogeneous sample at $530^{\circ} \mathrm{C}$ for 27 days at $P_{\mathrm{H}_{2} \mathrm{O}} 200 \mathrm{MPa}$ obtaining a similar periodicity to the 'dry' experiments, suggesting that the presence of water has no significant effect on coarsening rates. Hokanson and Yund (1986) compared Na-K interdiffusion coefficients from various studies and concluded that there was reasonable agreement, the main variable being crystal composition as the alkali feldspar solvus was approached and the solid solutions became more non-ideal. The effect of $P$ on diffusion rates is unknown but likely to be small. Parsons and Fitz Gerald (2011) found good, orderof-magnitude agreement between observed lamellar periodicities of ordered film microperthites in the Klokken pluton and those extrapolated from Yund and Davidson's experiments to $10^{4}-10^{5} \mathrm{y}$, corresponding with annealing times appropriate for a cooling history for the intrusion calculated by Brown and Parsons (1984a).

Brady (1987) carried out a least-squares analysis of Yund and Davidson's data and obtained an Arrhenius relationship for coarsening corresponding with:

$$
\begin{gathered}
k=\left(2.076 \times 10^{-14}\right) \exp (-139825 / R T) \\
{\left[k\left(\mathrm{~m}^{2} \mathrm{~s}^{-1}\right), \text { activation energy } E_{a}\left(\mathrm{~J} \mathrm{~mol}^{-1}\right), T(\mathrm{~K})\right]}
\end{gathered}
$$

Coarsening data are applied most readily to regular periodic intergrowths formed by spinodal decomposition, whereas the present intergrowths are irregular in distribution and formed by nucleation. However, provided we can be sure that there are no small lamellae intervening between large lamellae it is possible to estimate a maximum diffusion distance, $\lambda / 2$. The rate constant $k$ in (1) is equivalent to the diffusion coefficient $D$ in the approximation $x^{2}=D t$ where $x$ is the diffusion distance (m). A round-number estimate of the largest $\lambda / 2$ in Fig. $16 a$ is $\sim 1 \mu \mathrm{m}$. The $t$ calculated from (equation 1) to obtain an intergrowth with this diffusion dimension by isothermal annealing is shown as the lower curve on Fig. 18. It would require $0.11 \mathrm{My}$ at $400^{\circ} \mathrm{C}$, which would require $P$ of $\sim 1.5 \mathrm{GPa}, 8.4 \mathrm{My}$ at $300^{\circ} \mathrm{C}, \sim 1.0 \mathrm{GPa}$ and $4.2 \mathrm{~Gy}$ at $200^{\circ} \mathrm{C}$ and $\sim 0.5 \mathrm{GPa}$. While the first two values are feasible in crust undergoing regional metamorphism, coarsening by sustained annealing much below $300^{\circ} \mathrm{C}$ is clearly impossible. It may be that the extrapolation of the coherent solvus to the low $T$ implied by the bulk composition of $\mathrm{Or}_{93} \mathrm{Ab}_{7}$ is in error, or that the coarsening rates determined experimentally do not apply at lower $T$. However, sustained heating in the range $400-300^{\circ} \mathrm{C}$ at moderately high $P$ appears to be required to explain the strain-controlled film perthites in both pegmatites.

\section{Formation of replacement perthites}

\section{Perth vein macroperthite}

The coarse perthite in Perth is a sub-periodic intergrowth of microcline and albite veins (Figs 2, 3) $\sim 0.6 \mathrm{~mm}$ wide and spaced $\sim 1 \mathrm{~mm}$ apart in the cryptoperthitic microcline matrix. The cryptoperthite formed after the development of tartan twinning in the microcline below $500-450^{\circ} \mathrm{C}($ Figs 5,6$)$ and the veins formed after the cryptoperthite (Figs 3, 10), had coarsened in the range $400-300^{\circ} \mathrm{C}$ (Fig. 18), over a considerable time interval. The albite is of near end-member composition $\left(\sim \mathrm{Ab}_{99.2}\right.$, Table 1$)$, pointing to growth at very low $T$. The extreme irregularity of interfaces (Figs 3, 10), the development of subgrains and the accompanying turbidity, all point to formation by a replacement process involving interface-coupled dissolution and reprecipitation (Worden et al., 1990; Walker et al., 1995; Putnis, 2002; Parsons and Lee, 2009). Very coarse, sub-periodic vein intergrowths are frequently reported from pegmatites. Smith (1974, pp. 407-421) and Smith and Brown (1988, pp. 595$604)$ provide numerous illustrations. As we discuss below it is geologically implausible that such coarse intergrowths could form by diffusion.

Replacement in Perth is clearly non-isochemical because the bulk composition of the cryptoperthitic microcline $\left(\mathrm{Or}_{93} \mathrm{Ab}_{7}\right.$, Table 1$)$ is much less albitic than the bulk crystal $\left(\mathrm{Or}_{57} \mathrm{Ab}_{42} \mathrm{An}_{1}\right)$. Chemically, only $\mathrm{Na} \leftrightarrow \mathrm{K}$ exchange is involved in the replacement. An was below detection in the cryptoperthitic microcline and the replacive albite is $\mathrm{An}_{0.2}$ (Table 1). Long-range transport of $\mathrm{Si}$ and $\mathrm{Al}$ is not required. Dissolution of twinned microcline and replacement by albite subgrains presumably took place in advancing fluid films, as envisaged by Parsons and Lee (2009). Orville (1963) explained how alkalis are partitioned between an assemblage of two feldspars and an aqueous fluid, and how this could lead to 

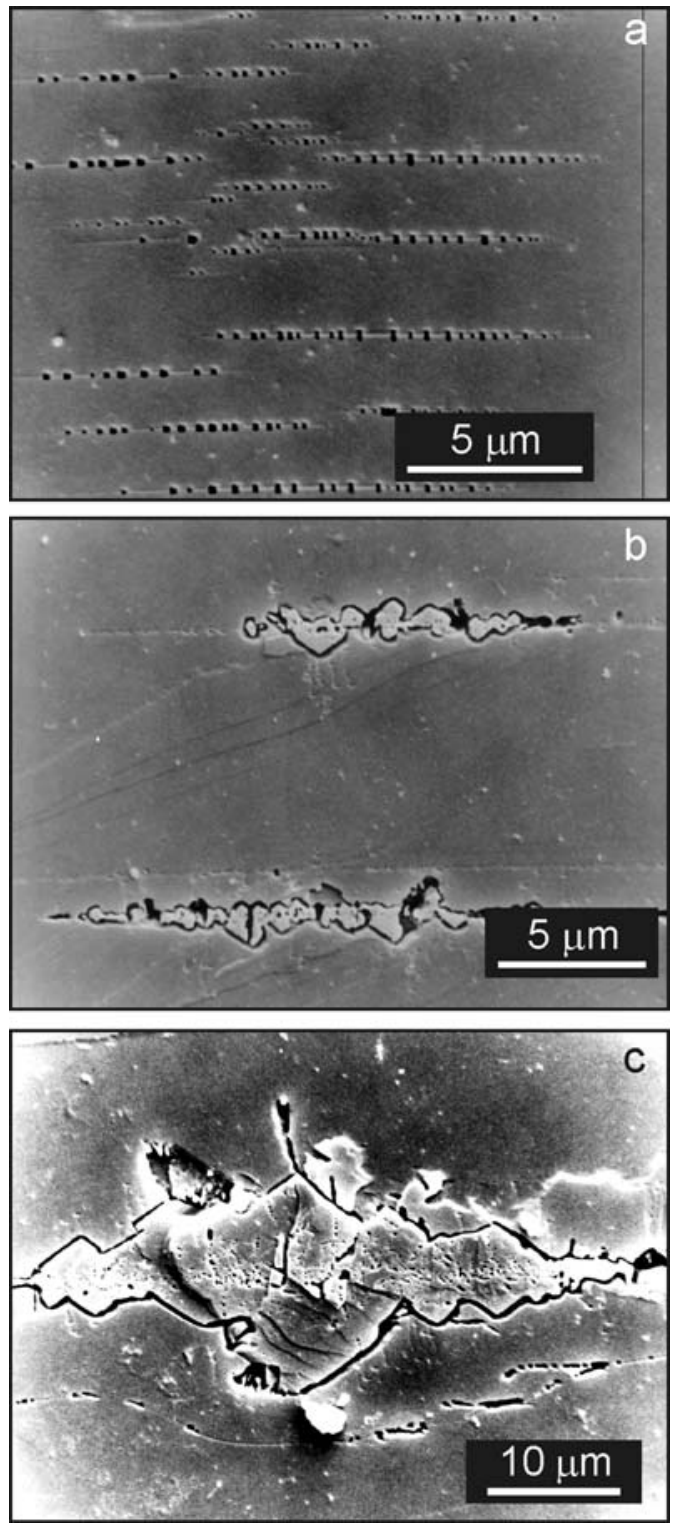

FIG. 17. Keystone. SE SEM images of (001) cleavage surfaces etched with HF vapour. (a) Etch pits on misfit dislocation loops encircling semicoherent cryptoperthitic albite lamellae. The lenticular albite has slight positive relief above the microcline matrix. (b) Region in which outgrowths of replacive albite, with the $\{110\}$ habit of pericline, have developed on cryptoperthic lamellae. Ghost-like lines of pores run through the region of overgrowth. (c) Considerably larger albite region with a well developed 'ghost' line of pores. alkali metasomatism (Orville, 1962). The importance of his work in feldspar microtextural evolution was reviewed by Parsons and Lee (2000). Provided the feldspars lie on the solvus, $\mathrm{Na}: \mathrm{K}$ in the fluid is a function only of $T$. Fluids in equilibrium with two feldspars at low $T$ have high Na:K, independently of the proportions of $\mathrm{Ab}$ - and Or-rich feldspar, and in a hydrothermal system with a $T$ gradient will reach equilibrium by precipitating K-feldspar at low $T$ and albite at higher $T$. The irregular microcline replacing albite in Fig. 8 would have been precipitated from a relatively cool fluid. Lee and Parsons (1998) found extensive replacement by microcline in feldspars from the Shap granite undergoing diagenesis. The dissolution of film albite lamellae leaving empty lenticular pores (Figs 7, 9) could also be a response to cooling. Elastic strain in coherent lamellae would mean that their albite would be more soluble than the unstrained albite mosaics forming the macroperthite.

Granitic pegmatites (like granites with low normative $A n$ ) usually have bulk compositions corresponding with minimum melting compositions in $\mathrm{Ab}-\mathrm{Or}-\mathrm{Q}-\mathrm{H}_{2} \mathrm{O}$ (e.g. London and Kontak, 2012). Orville (1960) showed that the compositions of the Keystone pegmatites correspond with liquidus minima in $\mathrm{Ab}-\mathrm{Or}-\mathrm{Q}$ at $\sim 200 \mathrm{MPa}$ (Tuttle and Bowen, 1958). The long established agreement (Tuttle and Bowen, 1958) between normative $A b$, Or and $Q$ calculated from analyses of granitoids and liquidus minima in the granite system precludes large-scale, subsolidus non-isochemical replacement at the scale of a rock sample, even when there is clear textural evidence for some non-isochemical replacement at the scale of a single alkali feldspar crystal. In the absence of data on the mineralogy of the pegmatite as a whole it is not possible to speculate on the source of the $\mathrm{Na}^{+}$, or the fate of the $\mathrm{K}^{+}$that has been replaced.

\section{Keystone vein perthite}

The coarsest vein perthite in Keystone (Fig. 15a) is on a similar scale to that in Perth, but it is more variable in scale, not obviously periodic and is overall orientated close to $\{110\}$. Andersen (1928) suggested that this type of vein perthite is replacive and that the $\sim\{110\}$ orientation is defined by contraction cracks. Alling (1938) recognized that non-isochemical replacement is likely to be localized near crystal edges, or follow fractures and cleavages, as in Keystone. A process of infiltration, 


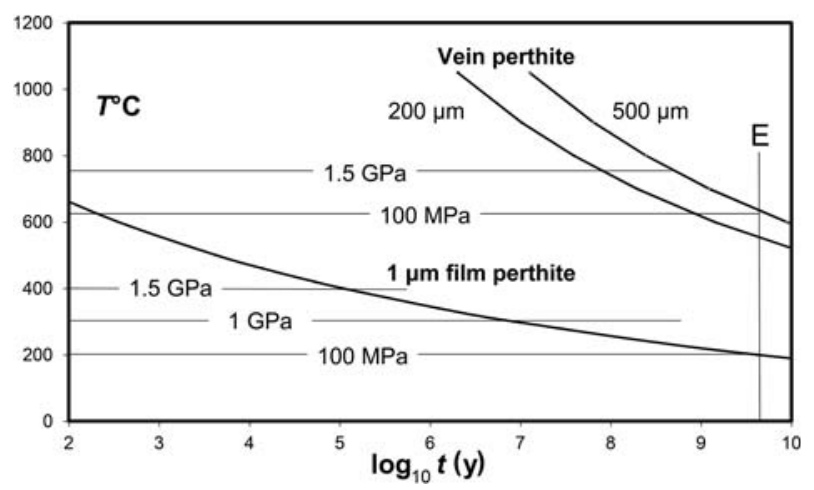

FIG. 18. Time taken to produce lamellar perthites of the specified periodicities by isothermal annealing, using $D$ obtained from experimental coarsening data of Yund and Davidson (1978), and the $x^{2}=D t$ approximation, where $x$ is half the lamellar periodicity. E is the age of Earth. Increasing $P$ raises solvus $T$ by $220 \mathrm{~K} \mathrm{GPa}^{-1}$ (Hovis et al., 1991 ). Microperthitic film lamellae with $\lambda / 2$ of $\sim 1 \mu \mathrm{m}$ (Figs $4,17 a$ ) would require annealing for $0.11 \mathrm{My}$ at $400^{\circ} \mathrm{C}$ and $10 \mathrm{My}$ at $300^{\circ} \mathrm{C}$ to form, but impossibly long times at $200^{\circ} \mathrm{C}$. Isotherms for hypothetical coherent precursors to the coarse replacive film macroperthites with periodicities of 0.4 and $1 \mathrm{~mm}$ are drawn at exsolution $T$ calculated at both high and low $P$. Even at high $P$ implausibly long periods of annealing would be required for the observed periodicities.

on various scales, into crack networks governed by the $\{110\}$ cleavage, which is often well developed in pegmatitic feldspars, seems to us to account well for the microtextures in Keystone. Planes in $\{110\}$ frequently develop in replacement perthites because of the growth of subgrains with the adularia (and pericline) habits (Worden et al. 1990; Parsons and Lee 2009). Figure 16 shows relics of cryptoperthitic film lamellae in a zone of sericitization surrounding the vein albite. The coarse albite veins therefore developed after the formation of the cryptoperthite at $<300^{\circ} \mathrm{C}$. The zone of altered $\mathrm{K}$-feldspar suggests that the fluid that was responsible for introducing the vein albite also led to local incomplete recrystallization of the microcline cryptoperthite. However, this recrystallized zone cannot have supplied all the albite in the veins, because the Ab-content of the matrix is only $6 \mathrm{~mol} \%$ (Table 1) and the recrystallization is incomplete. The Ab-component cannot have come from further afield in the microcline matrix while leaving the albite film lamellae unmodified. Like Perth, the Keystone vein perthite developed by replacement that was non-isochemical with respect to the bulk feldspar crystal, and perhaps involved plagioclase in the pegmatite.

\section{Development of periodic macroperthites by replacement}

It is not obvious to us how coarse periodic replacement perthites like those in both Perth samples form (Figs 1-3). Coarse perthitic intergrowths in pegmatitic feldspars are often subperiodic, sometimes on $\mathrm{mm}$ scales. A striking example was used for the cover of a special issue of The Canadian Mineralogist (vol. 46, pt. 6, 2008) dedicated to the work of J.V. Smith. Other examples can be found in Smith (1974) and Smith and Brown (1988). In this section we discuss possible mechanisms for their development.

\section{Coarsening and amalgamation of semi- coherent microperthitic film lamellae}

Lee and Parsons (1997) showed that in the Shap granite there was a late phase of large-scale albitization of orthoclase phenocrysts that started with the replacement of strained albite and Or-rich feldspar surrounding dislocations. The replacive albite then advanced into the Or-rich feldspar leading to irregular broadening of the microperthitic albite films (e.g. Lee and Parsons, 1997, figs 2, 3). Ultimately, large volumes of orthoclase were replaced. These replacive intergrowths clearly developed on the fine film lamellae but are not periodic over a large volume. Semi-coherent albite films are especially susceptible to interaction with fluids because of the misfit dislocations which are arranged in an orthogonal network over their surfaces (Aberdam, 1965; Waldron et al., 1994; Lee et al., 1995; Fitz Gerald et al., 2006). Once a fluid has gained access to one part of the dislocation network, dissolution or replacement can take place rapidly owing to the energetic advantage of 


\section{PERTHITES FROM PEGMATITES}

destruction of strained crystal structure surrounding the dislocations.

In Perth and Keystone the strain-controlled microtextures show good evidence for localized reactions with fluids subsequent to coarsening, i.e. below $\sim 300^{\circ} \mathrm{C}$. In thin section the films are partly turbid. EM work shows that albite films have in places been dissolved (Figs 7, 9), or replaced by irregular microcline (Fig. 8). Albite outgrowths have replaced microcline adjacent to films (Figs 17b,c). It is difficult to see how a progression of this process could lead to the coarse albite veins in Perth. Figures $3 b$ and 10 show that protrusions in the complex surface of the macroperthitic albite veins cut across matrix film lamellae, as they do in Keystone. The Ab-component could not have been extracted from the film microperthite. We conclude that local replacement of film lamellae (Figs $17 b, c$ ) is a minor, late process, perhaps related to formation of the coarse vein perthite, but not a step leading to its formation.

\section{Modification of precursor coarse coherent intergrowths}

The axes of the lenticular macroperthitic veins in Perth are slightly sinuous but overall roughly parallel to b (Fig. 2a) and will lie in or close to (100), not far from ( $\overline{6} 01)$, the plane of coherent film perthites. Lenticular lamellae in non-turbid mesoperthites in granulite facies rocks (see Rollinson, 1982, fig. 1; Evangelekakis et al. 1993, figs 2, 3; Cayzer, 2002; and Parsons and Lee, 2005, figs 16-18, for examples), which have periodicities up to $\sim 20 \mu \mathrm{m}$, are in $(\overline{6} 01)$. A possibility, therefore, is that the periodicity of the vein perthites in the pegmatites was derived from an initial phase of coherent exsolution at relatively high $T$ modified by dissolution-reprecipitation reactions at $<300^{\circ} \mathrm{C}$. In this model the microperthitic film lamellae in the matrix microcline (seen in both Perth and Keystone) would have formed at low $T$ in the stranded diffusion profile between the coarsened, high- $T$ lamellae. Similar 'stranded' lamellae, or 'platelets' are common in alkali feldspars from granitic rocks (e.g. Lee et al. 1995, fig. 15 and Parsons et al. 2010, fig. 7).

Estimates of minimum $T$ for crystal growth (as homogeneous crystals), and of maximum $T$ for the commencement of unmixing can be calculated for the bulk compositions of Perth and Keystone (Table 1) using the asumptions given in the section on development of strain-controlled microtextures above. The upper curves on Fig. 18 show that geologically unreasonable annealing times would be required to produce coherent intergrowths with the $>200 \mu \mathrm{m}$ diffusion lengths $(\lambda / 2)$ implied by Perth, even when exsolution occurred at high $P$ and $T$. These times rule out the possibility of a diffusioncontrolled precursor to the periodic vein perthites. Note that, in contrast, the $\leq 20 \mu \mathrm{m}$ periodicities of coherent and semicoherent film intergrowths in granulite facies feldspars could be produced by diffusion in $t<10^{7} \mathrm{y}$, geologically reasonable during granulite-facies metamorphism. Ternary mesoperthites from granulites usually have significant An, in some cases $>10 \mathrm{~mol} . \%$, which would increase the $T$ of the beginning of exsolution, but possibly slow coarsening rates because of $\mathrm{Ca}-\mathrm{Al}$ coupling.

\section{Strain-controlled replacement}

If a coherent precursor for periodic vein perthites is improbable, their mode of formation remains mysterious. The complex, fractal-like shapes of the surfaces of lamellae in Perth (Fig. 3b) hint of self-organization during an interface-coupled replacement process, but the origin of the periodic interleaving is not obvious.

Norberg et al. (2011) have recently published an interesting experimental study of albitization of a homogeneous sanidine (from Volkesfeld, Eifel) using concentrated $\mathrm{NaCl}$ solutions at $500^{\circ} \mathrm{C}$ and $200 \mathrm{MPa}$, in experiments lasting up to 16 days. The $T$ and chloride concentrations are both considerably higher than is likely for replacement in the pegmatite feldspars but the experiments nevertheless provide a possible solution to our problem. Norberg et al. found that angular albite blades with sharp, coherent or semicoherent interfaces penetrated the sanidine in a plane parallel to (100) or $(h 0 l)$, where $h$ is $>>1$ and therefore close to $(\overline{6} 01)$. They suggest that interfaces favoured by replacement reactions are controlled by minimization of coherency strain, in the same way as coherent film exsolution lamellae, and they provide TEM images of both coherent and semicoherent interfaces between sanidine and replacive albite. The replacive albite is microporous, with a marked porosity fabric in $(\overline{6} 01)$, and has a subgrain microtexture (their fig. 7) strongly reminiscent of the natural replacement microtextures imaged by Worden et al. (1990). Norberg et al.'s experiments are important because they show that replacement even of homogeneous sanidine may lead to intergrowths orientated by minimization of misfit between replaced and replacive phases, and might provide an explanation for the orientation of our coarse vein lamellae. In our samples development near the Murchison plane 
would be further enhanced by the presence of the semicoherent film lamellae, which predate the veins, and provide channels for replacement.

The albite-sanidine interface in the experiments of Norberg et al. (2011, fig. 2) was deeply serrated, with periodicities on the order of 50-200 $\mu \mathrm{m}$. Their images are viewed from the $\mathbf{b}$ direction, and it would be interesting to know the appearance of the serrations from near $\mathbf{c}^{*}$, the viewing direction of the images in the present paper (Figs 3,10). In principle we might expect large serrations to grow at the expense of small ones, because total inter-phase surface energies and coherency strains would in that way be minimized. It is possible that a selforganized, periodic structure might arise similar to the coarse veins in Perth. During albitization there is a decrease in volume which might lead to cracking and favour the advance of larger albite films by providing space at the advancing film tip. The slight angular difference between film lamellae in (601) and vein perthite in (100) (Smith, 1974, figs 19.4, 19.11) can be accounted for if the veins are composed of an assembly of replacive Albitetwinned $\{110\}$ subgrains.

\section{Pleated rims}

Another way in which film lamellae might coarsen during fluid-feldspar reactions to a periodic structure is a process that leads to microtextures called 'pleated rims' along the margins of braid microperthite crystals. These crystals are mesoperthites $\left(\mathrm{Ab}_{60} \mathrm{Or}_{40}\right)$ so this mechanism might apply to Perth $\left(\mathrm{Ab}_{42.0} \mathrm{Or}_{57.4} \mathrm{An}_{0.6}\right)$ but will not apply to Keystone, unless there was a precursor film microtexture that has been obliterated. Lee et al. (1997) described the complex coarsening process in feldspars from the Klokken intrusion. Coarsening of the braid texture starts by a process of 'phase separation' in which Ab- and Or-rich lamellae thicken near crystal margins into structures called 'pleats'. They form initially by volume diffusion, when the constraint of coherency strain on the orientation and thickness of the braid lamellae is relieved by adjustment in the crystal boundary. In the advancing 'head' of the pleat, lamellae in the braid orientation $\{\overline{6} \overline{6} 1\}$ rotate into the $(\overline{6} 01)$ orientation of film lamellae which develop misfit dislocations which facilitate fluid access into the crystal. These develop into subperiodic 'vein perthites' which in some cases (figs 7a,b in Lee et al., 1997) extend entirely across mmscale crystals. Similar structures at interfaces between braid and patch perthite within crystals undergoing deuteric coarsening are illustrated by Parsons and Lee (2009, fig. 5, point C). The periodicities, $\sim 20 \mu \mathrm{m}$, are much smaller than the coarse vein perthites in the present study, but Klokken cooled comparatively rapidly and has not been subject to long periods of annealing (see Parsons and Fitz Gerald, 2011). The Klokken patch perthites are strikingly similar to those produced experimentally by Norberg et al. (2013).

\section{Development of semicoherent Albite twins in albite}

An interesting feature of the coarse macroperthitic albite lamellae in Perth is the occurrence of dislocations on Albite twin composition planes (Figs 11-14). Similar dislocations occur in Keystone. Dislocations on the composition plane of Albite twins are anomalous because there is normally no lattice misfit and twins are fully coherent (Smith and Brown, 1988). Etch pits orientated in lines parallel to (010) were described on HF acid etched plagioclase by Lundström (1970). These pits, in an andesine $\left(\mathrm{An}_{45}\right)$ and a pegmatitic oligoclase $\left(\mathrm{An}_{19}\right)$, were interpreted like ours to have formed by the etching of dislocations on Albite twin composition planes. Textures of Albite twins in the andesine described by Lundström indicated a glide origin (i.e. the twins had formed in response to shear stress). The implication of Lundström's work is that the dislocations are genetically related to the formation of glide twins.

Smith and Brown (1988) summarize the criteria for differentiating growth and glide twins. Growth twins are usually of low to moderate frequency, often have stepped composition surfaces and may stop abruptly, and may thicken and thin independently of each other. Glide twins typically occur in clusters which change in thickness sympathetically, often taper to a point and are often related to internal deformational features. Albite twins in Figs 11-14 show considerable variation in thickness, often have steps in composition planes and on these criteria conform with growth twins, as would be expected from their occurrence in replacive subgrains. Small steps in composition planes are clearly associated with dislocations. The structural misfit at the curved end of an albite twin in Fig. 14 has been accommodated by an intense row of closely-spaced dislocations.

On the other hand, there are observations that support a shear-related origin for the dislocations. 
The grooves on the etched (001) surfaces of Albite twins (Fig. 12) are caused by differential etching reflecting an inhomogeneous distribution of elastic strain energy. The stress has been accommodated by compression of $\{110\}$ planes. Dislocations are observed where regions of elastically strained crystal structure orientated parallel to (110) and $(1 \overline{1} 0)_{\text {albite }}$ intersect at the twin composition plane. This model is further supported by the fact that the strain fields surrounding the dislocations, which have been etched to form the pits, extend into the body of the Albite twin parallel to $\{110\}$.

Some observations suggest that formation of at least some of the dislocations post-dates Albite twinning. Some twins have no dislocations on either side, and lines of dislocations can branch off from the twin composition plane into the interior of the twin (Fig. 12). In addition, the irregularity in distribution of dislocations is curious; on one side of a twin individual many dislocations may be present, whereas on the other side they may be completely absent.

We suggest that most Albite twins formed during replacive growth, and that some dislocations formed to minimize misfit where the advance of a twin was terminated (Figs 11, 14). The periodic dislocation arrays at contacts between albite subgrains, and between albite and K-feldspar subgrains, produced experimentally by Norberg et al. (2011) and those imaged by Lee and Parsons (1997), between orthoclase and natural replacive albite, are of a similar type. Other dislocations, on straight Albite twin composition planes (Figs 12, 13), and the long-range strain (Fig. 12), developed subsequently during minor deformation.

\section{Conclusions}

The pegmatitic alkali feldspar from Perth, Ontario, supplied by Wards (46 E 0510) is a microcline macromesoperthite (bulk $\mathrm{Ab}_{42} \mathrm{Or}_{57} \mathrm{An}_{1}$ ). It differs both in microtextures and bulk composition from a sample of the type perthite (Hunterian M2631) $\left(\mathrm{Ab}_{56} \mathrm{Or}_{41} \mathrm{An}_{3}\right)$ from the same general location. The sample from Keystone, South Dakota, (Wards $46 \mathrm{E}$ 5125), is a microcline microperthite $\left(\mathrm{Ab}_{21} \mathrm{Or}_{78} \mathrm{An}_{1}\right)$.

Perth microcline has a regular 'tartan' twin microtexture of sub- $\mu \mathrm{m}$ periodicity and does not have a sub-grain microtexture. The microcline formed by a continuous diffusional process. Keystone microcline has thicker, more variable, spindle-section twins. Subgrains occur, with associated micropores and volumes of irregular microcline. They formed by pervasive dissolution- reprecipitation. The microcline of both samples contains sub- $\mu \mathrm{m}$ coherent and semicoherent albite films close to $(\overline{6} 01)$. In Perth the Albite twins in the albite films have widths defined by twins in the microcline. Coherent exsolution occurred after the development of 'tartan' twinning, in the microcline field. The bulk composition of the microcline plus included albite films $\left(\mathrm{Or}_{93}\right)$ implies that coherent exsolution would have begun at $\sim 90^{\circ} \mathrm{C}$ at $0.1 \mathrm{GPa}$, $\sim 180^{\circ} \mathrm{C}$ at $0.5 \mathrm{GPa}$ and $\sim 400^{\circ} \mathrm{C}$ at $1.5 \mathrm{GPa}$. Diffusion parameters imply sustained heating for between $0.11 \mathrm{My}$ at $\sim 400^{\circ} \mathrm{C}$ and $8.4 \mathrm{My}$ at $\sim 300^{\circ} \mathrm{C}$ to develop these microtextures. Implausibly long annealing would be required at $200^{\circ} \mathrm{C}$. Some semicoherent lamellae were later affected by dissolution leaving lenticular pores, and some were replaced by irregular microcline. In Keystone, replacive incoherent albite outgrowths have developed on the lamellae.

Perth contains sub-periodic veins of very pure albite $\left(A b_{>99}\right)$, close to (100), with extremely complex surfaces. They are up to $1 \mathrm{~mm}$ in thickness and separation, cross-cut the coherent microperthites, are constructed of incoherent and semicoherent subgrains, and formed by interface-coupled replacement of the cryptoperthitic microcline. It is not obvious how the periodicity of coarse replacive perthitic intergrowths develops. Implausibly long times are required to produce $\mathrm{mm}$-scale lamellae by diffusion, ruling out the possibility that they represent deuteric recrystallization of coarse coherent precursors. Experimental work by Norberg et al. (2011) shows that replacive lamellae can be orientated in $(\overline{6} 01)$ [i.e. close to $(100)$ ] because they are initially coherent, and that advancing interfaces have a saw-tooth shape on scales of tens of $\mu \mathrm{m}$. The periodic macroperthites might have formed in a similar way. In Keystone, coarse albite veins are not periodic and probably follow contraction cracks on the $\{110\}$ cleavage. Replacement was non-isochemical on the scale of a single crystal but liquid-crystal relationships in the 'granite' system $\mathrm{Ab}-\mathrm{Or}-\mathrm{Q}$ require that the albite was locally derived.

Unusually, dislocations occur on Albite twin composition planes in the Perth vein albite. Some formed in response to coalescence of precursor albite films during fluid-induced coarsening. Curving arrays away from composition planes resulted from tectonic deformation. The microtextures in the Wards samples differ considerably from those encountered in alkali feldspars from granitic and syenitic rocks of normal grain-size. They are not suitable samples for obtaining 
generically applicable data on dissolution rates and thermoluminescence fading, for which they have been used in the past.

\section{Acknowledgements}

The authors thank the Natural Environment Research Council for funding this research through grant NER/ A/S/2003/00346 and John Faithful, of the Hunterian Museum in Glasgow, for supplying material from the type perthite.

\section{References}

Aberdam, D. (1965) Utilisation de la microscopie electronique pour l'etude des feldspaths: observations sur des microperthites. Science de la Terre, 6, 1-76.

Alling, H.L. (1921) The mineralography of the feldspars. Journal of Geology, 29, 193-294.

Alling, H.L. (1932) Perthites. American Mineralogist, 17, 43-65.

Alling, H.L. (1938) Plutonic perthites. Journal of Geology, 46, 142-165.

Anbeek, C. (1992) The dependence of dissolution rates on grain size for some fresh and weathered feldspars. Geochimica et Cosmochimica Acta, 56, 3957-3970.

Andersen, O. (1928) The genesis of some types of feldspar from granite pegmatites. Norsk Geologisk Tidsskrift, 10, 116-207.

Arnaud, N.O. and Kelley, S.P. (1997) Argon behaviour in gem-quality orthoclase from Madagascar: Experiments and some consequences for ${ }^{40} \mathrm{Ar} /{ }^{39} \mathrm{Ar}$ geochronology. Geochimica Cosmochimica Acta, 61, 3227-3255.

Bachinski, S.W. and Müller, G. (1971) Experimental determination of the microcline - low albite solvus. Journal of Petrology, 12, 329-356.

Balić-Źunić, T., Piazolo, S., Katerinopoulou, A. and Schmith, J.H. (2013) Full analysis of feldspar texture and crystal structure by combining X-ray and electron techniques. American Mineralogist, 98, 41-52.

Bambauer, H.U., Krause, C. and Kroll, H. (1989) TEM investigation of the sanidine/microcline transition across metamorphic zones. European Journal of Mineralogy, 1, 47-58.

Baril, M.C. and Huntley, D.J. (2003) Infrared stimulated luminescence and phosphorescence spectra of irradiated feldspars. Journal of Physics: Condensed Matter, 15, 8029-8048.

Brady, J.B. (1987) Coarsening of fine-scale exsolution lamellae. American Mineralogist, 72, 697-706.

Brantley, S.L. and Mellott, N.P. (2000) Surface area and porosity of primary silicate minerals. American Mineralogist, 85, 1767-1783.

Brown, W.L. and Parsons, I. (1984a) Exsolution and coarsening mechanisms and kinetics in an ordered cryptoperthite series. Contributions to Mineralogy and Petrology, 86, 3-18.

Brown, W.L. and Parsons, I. (1984b) The nature of potassium feldspar, exsolution microtextures and development of dislocations as a function of composition in perthitic alkali feldspars. Contributions to Mineralogy and Petrology, 86, 335-341.

Brown, W.L. and Parsons, I. (1988) Zoned ternary feldspars in the Klokken intrusion: exsolution textures and mechanisms. Contributions to Mineralogy and Petrology, 98, 444-454.

Brown, W.L. and Parsons, I. (1989) Alkali feldspars: ordering rates, phase transformations and behaviour diagrams for igneous rocks. Mineralogical Magazine, 53, 25-42.

Brown, W.L. and Parsons, I. (1993) Storage and release of elastic strain energy: the driving force for low temperature reactivity and alteration of alkali feldspars. Pp. 267-290 in: Defects and Processes in the Solid State: Geoscience Applications (The McLaren Volume) (J.N. Boland and J.D. Fitz Gerald, editors). Elsevier, Amsterdam, $470 \mathrm{pp}$.

Brown, W.L., Becker, S.M. and Parsons, I. (1983) Cryptoperthites and cooling rate in a layered syenite pluton. Contributions to Mineralogy and Petrology, 82, 13-25.

Carpenter, M.A. and Salje, E.K.H. (1994) Thermodynamics of nonconvergent cation ordering in minerals. American Mineralogist, 79, 1084-1098.

Cayzer, N. (2002) Feldspar microtextures and the cooling histories of high-grade terrains. $\mathrm{PhD}$ thesis, University of Edinburgh, UK, 300 pp.

Černý, P. (1994) Evolution of feldspars in granitic pegmatites. Pp. 501-540 in: Feldspars and Their Reactions (I. Parsons, editor). NATO ASI Series, C 421, Kluwer Academic Publishers, Dordrecht, 650 pp. Coombs, D.S. (1954) Ferriferous orthoclase from Madagascar. Mineralogical. Magazine, 30, 409-427.

Eggleton, R.A. and Buseck, P.R. (1980) The orthoclasemicrocline inversion: a high-resolution transmission electron microscope study and strain analysis. Contributions to Mineralogy and Petrology, 74, 123-133.

Evangelekakis, C., Kroll, H., Voll, G., Wenk, H.-R., Meisheng, H. and Köpcke, J. (1993) Low-temperature coherent exsolution in alkali feldspars from high-grade metamorphic rocks of Sri Lanka. Contributions to Mineralogy and Petrology, 114, 519-532.

Fitz Gerald, J.D. and McLaren, A.C. (1982) The microstructures of microcline from some granitic rocks and pegmatites. Contributions to Mineralogy and Petrology, 80, 219-229.

Fitz Gerald, J.D., Parsons, I. and Cayzer, N. (2006) Nanotunnels and pull-aparts: Defects of exsolution lamellae in alkali feldspars. American Mineralogist, 91, 772-783. 
Foland, K.A. (1974) ${ }^{40} \mathrm{Ar}$ diffusion in homogeneous orthoclase and an interpretation of $\mathrm{Ar}$ diffusion in K-feldspar. Geochimica Cosmochimica Acta, 38, 151-166.

Godfrey-Smith, D.I., Scallion, P. and Clarke, M.L. (2005) Beta dosimetry of potassium feldspars in sediment extracts using imaging microprobe analysis and beta counting. Geochronometria, 24, 7-12.

Hodson, M.E. (1998) Micropore surface area variation with grain size in unweathered alkali feldspars: Implications for surface roughness and dissolution studies. Geochimica et Cosmochimica Acta, 62, 3429-3435.

Hodson, M.E., Lee, M.R. and Parsons, I. (1997) Origins of the surface roughness of unweathered alkali feldspar grains. Geochimica et Cosmochimica Acta, 61, 3885-3896.

Hokanson, S.A. and Yund, R.A. (1986) Comparison of alkali interdiffusion rates for cryptoperthites. American Mineralogist, 71, 1409-1414.

Holdren, G.R., Jr. and Speyer, P.M. (1985) Reaction ratesurface area relationships during the early stages of weathering-I. initial observations. Geochimica et Cosmochimica Acta, 49, 675-681.

Holdren, G.R., Jr. and Speyer, P.M. (1987) Reaction rate-surface area relationships during the early stages of weathering-II. Data on eight additional feldspars. Geochimica et Cosmochimica Acta, 51, 2311-2318.

Hovis, G.L., Delbove, F. and Roll Bose, M. (1991) Gibbs energies and entropies of K-Na mixing for alkali feldspars from phase equilibrium data: Implications for feldspar solvi and short-range order. American Mineralogist, 76, 913-927.

Hunt, T.S. (1851) Examinations of some Canadian minerals. Philosophical Magazine, Series 4 (1), 322-328.

Keefer, K.D. and Brown, G.E. (1978) Crystal structures and compositions of sanidine and high albite in cryptoperthitic intergrowth. American Mineralogist, 63, 1264-1273.

Kroll, H., Krause, C. and Voll, G. (1991) Disordering, reordering and unmixing in alkali feldspars from contact-metamorphosed quartzites. Pp. 267-296 in: Equilibrium and Kinetics in Contact Metamorphism. (G. Voll, J. Töpel, D.R.M. Pattison and F. Seifert, editors). Springer-Verlag, Berlin.

Laves, F. and Soldatos, K. (1962) Plate perthite, a new perthitic intergrowth in microcline single crystals, a recrystallization product. Zeitschrift für Kristallographie, 117, 218-226.

Laves, F. and Soldatos, K. (1963) Die Albit/MikroklinOrientierungs-Beziehungen in Mikroklin-Verzwillinging und über unsymmetrische Albitausscheidung in Kryptoperthit. Zeitschrift für Kristallographie, 118, 69-102.
Lee, M.R. and Parsons, I. (1995) Microtextural controls of weathering of perthitic alkali feldspars. Geochimica et Cosmochimica Acta, 59, 4465-4488.

Lee, M.R. and Parsons, I. (1997) Dislocation formation and albitization in alkali feldspars from the Shap granite. American Mineralogist, 82, 557-570.

Lee, M.R. and Parsons, I. (1998) Microtextural controls of diagenetic alteration of detrital alkali feldspars: a case study of the Shap conglomerate (Lower Carboniferous), North-west England. Journal of Sedimentary Research, 68, 198-211.

Lee, M.R., Waldron, K.A. and Parsons, I. (1995) Exsolution and alteration microtextures in alkali feldspar phenocrysts from the Shap granite. Mineralogical Magazine, 59, 63-78.

Lee, M.R., Waldron, K.A., Parsons, I. and Brown, W.L. (1997) Feldspar-fluid interactions in braid microperthites: pleated rims and vein microperthites. Contributions to Mineralogy and Petrology, 127, 291-304.

Lee, M.R., Hodson, M.E. and Parsons, I. (1998) The role of intragranular microtextures and microstructures in chemical and mechanical weathering: direct comparisons of experimentally and naturally weathered alkali feldspars. Geochimica et Cosmochimica Acta, 62, 2771-2788.

Lee, M.R., Parsons, I., Edwards, P. and Martin, R.W. (2007) Identification of cathodoluminescence activators in zoned alkali feldspars by hyperspectral imaging and electron-probe microanalysis. American Mineralogist, 92, 243-253.

London, D. and Kontak, D.J. (2012) Granitic pegmatites: scientific wonders and economic bonanzas. Elements, 8, 257-261.

Lundström, I. (1970) Etch pattern and albite twinning in two plagioclases. Arkiv för Mineralogi och Geologi, 5, 63-91.

MacKenzie, W.S. and Smith, J.V. (1962) Single crystal $\mathrm{X}$-ray studies of crypto- and micro-perthites. Norsk Geologisk Tidsskrift, 42, 72-103 [Feldspar Volume].

Meisl, N.K. and Huntley, D.J. (2005) Anomalous fading parameters and activation energies of feldspars. Ancient TL, 23, 1-7.

Norberg, N., Neusser, G., Wirth, R. and Harlov, D. (2011) Microstructural evolution during experimental albitization of K-rich alkali feldspar. Contributions to Mineralogy and Petrology, 162, 531-546.

Norberg, N., Harlov, D., Neusser, G., Wirth, R., Rhede, D. and Moralez, L. (2013) Experimental development of patch perthite from synthetic cryptoperthite: Micro structural evolution and chemical equilibration. American Mineralogist, 98, 1429-1441.

Orville, P.M. (1960) Petrology of several pegmatites in the Keystone district, Black Hills, South Dakota. Bulletin of the Geological Society of America, 71, 1467-1490. 
Orville, P.M. (1962) Alkali metasomatism and feldspars. Norsk Geologisk Tidsskrift, 42, 238-316.

Orville, P.M. (1963) Alkali ion exchange between vapor and feldspar phases. American Journal of Science, 261, 210-237.

Parsons, I. (1978) Feldspars and fluids in cooling plutons. Mineralogical Magazine, 42, 1-17.

Parsons, I. (2010) Feldspars defined and described: a pair of posters published by the Mineralogical Society. Sources and supporting information. Mineralogical Magazine, 74, 529-551.

Parsons, I. and Brown, W.L. (1984) Feldspars and the thermal history of igneous rocks. Pp. 317-371 in: Feldspars and Feldspathoids. Structures, Properties and Ocurrences (W.L. Brown, editor). D. Reidel Publishing Company, Dordrecht, The Netherlands.

Parsons, I. and Brown, W.L. (1991) Mechanisms and kinetics of exsolution - structural control of diffusion and phase behavior in alkali feldspars. Pp. 304-344 in: Diffusion, atomic ordering and mass transport. Advances in Physical Geochemistry vol. 8. (J. Ganguly, editor). Springer-Verlag, New York, Berlin, 567 pp.

Parsons, I. and Fitz Gerald, J.D. (2011) Coarsening kinetics of coexisting peristerite and film microperthite over $10^{4}$ to $10^{5}$ years. American Mineralogist, 96, 1575-1584.

Parsons, I. and Lee, M.R. (2000) Alkali feldspars as microtextural markers of fluid flow. Pp. 27-50 in: Hydrogeology of Crystalline Rocks (I. Stober and K. Bucher, editors). Kluwer Academic Publishers, Dordrecht, The Netherlands, 292 pp.

Parsons, I. and Lee, M.R. (2005) Minerals are not just chemical compounds. The Canadian Mineralogist, 43, 1959-1992.

Parsons, I. and Lee, M.R. (2009) Mutual replacement reactions in alkali feldspars I: Microtextures and mechanisms. Contributions to Mineralogy and Petrology, 157, 641-661.

Parsons, I., Thompson, P., Lee, M.R. and Cayzer, N. (2005) Alkali feldspar microtextures as provenance indicators in siliciclastic rocks and their role in feldspar dissolution during transport and diagenesis. Journal of Sedimentary Research, 75, 921-942.

Parsons, I., Steele, D., Lee, M.R. and Magee, C. (2008) Titanium as a cathodoluminescence activator in alkali feldspars. American Mineralogist, 93, 875-879.

Parsons, I., Magee, C., Allen, C., Shelley, M.J. and Lee, M.R. (2009) Mutual replacement reactions in alkali feldspars II: Trace element partitioning and geothermometry. Contributions to Mineralogy and Petrology, 157, 663-687.

Parsons, I., Fitz Gerald, J.D., Lee, J.K.W., Ivanic, T. and Golla-Schindler, U. (2010) Time-temperature evolution of microtextures and contained fluids in a plutonic alkali feldspar during heating. Contributions to Mineralogy and Petrology, 160, 155-180.

Parsons, I., Fitz Gerald, J.D., Heizler, M.T., Heizler, L.L., Ivanic, T. and Lee, M.R. (2013) Eight-phase alkali feldspars: Low-temperature cryptoperthite, peristerite and multiple replacement reactions in the Klokken intrusion. Contributions to Mineralogy and Petrology, 165, 931-961.

Parsons, I., Fitz Gerald, J.D. and Lee, M.R. (2015) Routine characterization and interpretation of complex alkali feldspar intergrowths. American Mineralogist, 100, 1277-1303.

Putnis, A. (2002) Mineral replacement reactions: from macroscopic observations to micropscopic mechanisms. Mineralogical Magazine, 66, 689-708.

Rogers, J.R. and Bennett, P.C. (2004) Mineral stimulation of subsurface microorganisms: release of limiting nutrients from silicates. Chemical Geology, 203, 91-108.

Rollinson, H.R. (1982) Evidence from feldspar compositions of high temperatures in granite sheets in the Scourian complex, NW Scotland. Mineralogical Magazine, 46, 73-76.

Sánchez-Muñoz, L., Nistor, N., Van Tendeloo, G. and Sanz, J. (1998) Modulated structures in $\mathrm{KAlSi}_{3} \mathrm{O}_{8}$ : a study by high resolution electron microscopy and ${ }^{29} \mathrm{Si}$ MAS-NMR spectroscopy. Journal of Electron Microscopy, 47, 17-28.

Sánchez-Muñoz, L., Correcher, V., Turrero, M.J., Cremades, A. and García-Guinea, J. (2006) Visualization of elastic strain fields by the spatial distribution of the blue luminescence in a twinned microcline crystal. Physics and Chemistry of Minerals, 33, 639-650.

Sánchez-Muñoz, L., García-Guinea, J., Beny, J.-M., Rouer, O., Campos, R., Sanz, J. and de Moura, O.J. M. (2008) Mineral self-organization during the orthoclase-microcline transformation in a granite pegmatite. European Journal of Mineralogy, 20, 439-446.

Sánchez-Muñoz, L., García-Guinea, J., Zagorsky, V.Y., Juwono, T., Modreski, P.J., Cremades, A., Van Tendeloo, G. and De Moura, O.J.M. (2012) The evolution of twin patterns in perthitic K-feldspar from granitic pegmatites. The Canadian Mineralogist, 50, 989-1024.

Sheets, J.M. and Tettenhorst, R.T. (1997) Crystallographic controls on the alteration of microcline perthites from the Spruce Pine District, North Carolina. Clays and Clay Minerals, 45, 404-417.

Smith, J.V. (1974) Feldspar Minerals, first edition, volume 2. Springer Verlag, Berlin, pp. 690.

Smith, J.V. and Brown, W.L. (1988) Feldspar Minerals, second edition, volume 1. Springer Verlag, Berlin, pp. 828. 


\section{PERTHITES FROM PEGMATITES}

Soldatos, K. (1962) Über die kryptoperthitische AlbitAusscheidung in Mikroklinperthiten. Norsk Geologisk Tidskrifft, 42(2), 180-192.

Stoessell, R.K. and Pittman, E.D. (1990) Secondary porosity revisited: the chemistry of feldspar dissolution by carboxylic acids and anions. American Association of Petroleum Geologists Bulletin, 74, 1795-1805.

Thomson, T. (1843) Notice of some new Minerals. Philosophical Magazine, Series 3, 22, 188-194.

Tuttle, O.F. and Bowen, N.L. (1958) Origin of granite in the light of experimental studies in the system $\mathrm{NaAlSi}_{3} \mathrm{O}_{8}-\mathrm{KAlSi}_{3} \mathrm{O}_{8}-\mathrm{SiO}_{2}-\mathrm{H}_{2} \mathrm{O}$. Geological Society of America, Memoir, 74, xi +153.

Waldron, K.A., Parsons, I. and Brown, W.L. (1993) Solution-redeposition and the orthoclase-microcline transformation: evidence from granulites and relevance to ${ }^{18} \mathrm{O}$ exchange. Mineralogical Magazine, 57, 687-695.

Waldron, K.A., Lee, M.R. and Parsons, I. (1994) The microstructures of perthitic alkali feldspars revealed by hydrofluoric acid etching. Contributions to Mineralogy and Petrology, 116, 360-364.

Walker, F.D.L., Lee, M.R. and Parsons, I. (1995) Micropores and micropermeable texture in alkali feldspars: geochemical and geophysical implications. Mineralogical Magazine, 59, 505-534.

Wartho, J-A., Kelley, S.P., Brooker, R.A., Carroll, M.R., Villa, I.M. and Lee, M.R. (1999) Direct measurement of Ar diffusion profiles in a gem-quality Madagascar K-feldspar using the ultra-violet laser ablation microprobe (UVLAMP). Earth and Planetary Science Letters, 170, 141-153.

White, J.C. and Barnett, R.L. (1990) Microstructural signatures and glide twins in microcline, Hemlo, Ontario. The Canadian Mineralogist, 28, 757-769.

Willaime, C. and Brown, W.L. (1974) A coherent elastic model for the determination of the orientation of exsolution boundaries: application to the feldspars. Acta Crystallographica A, 30, 313-331.

Willaime, C. and Gandais, M. (1972) Study of exsolution in alkali feldspars. Calculation of elastic stresses inducing periodic twins. Physics Status Solidi (a), 9, 529-539.

Worden, R.H., Walker, F.D.L., Parsons, I. and Brown, W. L. (1990) Development of microporosity, diffusion channels and deuteric coarsening in perthitic alkali feldspars. Contributions to Mineralogy and Petrology, 104, 507-515.

Yund, R.A. (1974) Coherent exsolution in the alkali feldspars. Pp. 173-183 in: Geochemical Transport and Kinetics (A.W. Hofmann, B.J. Giletti, H.S. Yoder, Jr. and R.A. Yund, editors). Carnegie Institution of Washington publication 634.

Yund, R.A. and Davidson, P. (1978) Kinetics of lamellar coarsening in cryptoperthites. American Mineralogist, 63, 470-477. 